\title{
SPORTS PSYCHOLOGY IN SERBIA: A CRITICAL REVIEW OF THE PAST, CURRENT CONDITION AND FUTURE CHALLENGES
}

\author{
PSICOLOGÍA DEPORTIVA EN SERBIA: REVISIÓN CRÍTICA DE LA \\ DISTANCIA RECORRIDA, SITUACIÓN ACTUAL Y DESAFÍOS FUTUROS
}

\author{
Ljubica Bačanac \\ Faculty for Sports Management, University Donja Gorica, Podgorica, Montenegro
}

\begin{abstract}
An overview of key moments in the development of world's and domestic sports psychology has been presented herein, with an emphasis on the specificities and similarities accompanying this development. By defining sports psychology through the presentation of national development as well as through the subject matters of sport psychologists' study and activities, the richness of contents and topics it deals with has been pointed out. The development of national sports psychology and exercise has been monitored through its presence and growth within professional and academic institutions in the field of sports and physical education and through important events, publications and names of the individuals who have marked its beginnings, contributed significantly to its development, affirmation and recognition, and paved the path for a new generation of experts who will design its notable presence and plan its future development in the Serbian sports and academic community. The paper also includes a critical review of the current state of applied and academic sports psychology, accompanied by the recommendations of the necessary activities that will provide a way to its faster and even more successful development in the future.
\end{abstract}

Key words: SPORTS PSYCHOLOGY / DEVELOPMENT/ PERSPECTIVES / FUTURE CHALLENGES / SERBIA

\section{INTRODUCTION}

Today, after more than half a century of sports psychology in Serbia (within the SFRY, FRY, SCG) and for more than a decade of its development in the independent state the Republic of Serbia, it is important to recall the challenges and problems that followed its development, in the mission of its response to scientific and practical challenges, the needs and expecta-

\section{EXTRACTO}

Se ha dado una revisión de los momentos claves en el desarrollo de la psicología deportiva mundial y nacional destacando las cosas específicas y similares que acompañaban ese desarrollo. Definiendo la psicología deportiva a través de la presentación del desarrollo nacional, así como también a través del objeto de estudio y actividades de los psicólogos deportivos, se indicó la riqueza del contenido y temas que trata. El crecimiento de la psicología nacional de deporte y de ejercicios se ha seguido a través de su presencia y maduración en las instituciones profesionales y académicas en el sector del deporte y la educación física y a través de los eventos importantes, publicaciones y nombres de individuos que marcaron sus inicios, contribuyeron considerablemente a su desarrollo, afirmación y reconocimiento y trazaron el camino para nuevas generaciones de expertos que programarán su notable presencia y su futuro desarrollo en la comunidad deportiva y académica de Serbia. El trabajo contiene también una revisión crítica del momento actual de la psicología aplicada y académica del deporte, con las recomendaciones de actividades necesarias que abrirán el camino a su futuro desarrollo más rápido y todavía más exitoso.

Palabras claves: PSICOLOGÍA DEPORTIVA / DESARROLLO / PERSPECTIVAS / DESAFÍOS FUTUROS / SERBIA tions of athletes, coaches, parents of athletes, sports experts, academic community, as well as other actors in the national sports system. Why sports psychology has become so important is the first question that requires a comprehensive and purposeful answer. In the search for the answer, knowledge of the area of history of a scientific discipline is necessary for a bet- 
ter and deeper understanding of its present and more competent planning of its future development.

History teaches us that the development of sports psychology in Serbia was not as a straight and upward line, but that it had its ups and downs. This pendular development (according to the pendulum system) is logical because it took place in different socio-political contexts through which the Serbian society was passing, and which inevitably influenced sport determining its ideology, philosophy, politics, priority goals, but also the place and the role of sports science in its academic development and development with the aim of improving immediate sport practice.

The intention is, by illuminating the main features and achievements of sports psychology in two time periods (44 years of its development and functioning in Serbia within the Socialist Federal Republic of Yugoslavia and the Federal Republic of Yugoslavia, i.e. the state union of Serbia and Montenegro, and 12 years in the independent state of the Republic Serbia), points to the main problems it faced, how they were overcome, what place and role it played in improving sports practice and science. After these two periods, the question arises whether the sports psychology has justified the expectations of the professional public and managed to tackle the numerous prejudices and myths that have always followed it.

This analysis strives to examine the starting point, the current state and perspectives of the future mission and the development of sports psychology. The analysis has also encompassed the activities of both sport psychologists - practitioners and those who are more academically oriented. The same is expected to point out what weaknesses and what good sides of the current development of this inter-and multidisciplinary scientific discipline were, according to which the analysis should emphasize the areas of sports psychology that were either rightly or unjustifiably remained neglected and to pay much more strategic attention in the future to reach the goal, which is the rounding-off of the whole being of sports psychology.

The outcomes of the analysis should encourage current and future sport psychologists to develop, to fulfil their everyday work with curiosity that will lead to a higher level of professional competence and selfconfidence, to assert professional and ethical standards in their work with the challenges of future aspirations. Also, the intention is to point to the dominant roles and fields of professional and scientific research practice of sport psychologists in the past and today, and to highlight the possible trends of its further development.

\section{Sports psychology as a Scientific Discipline and a Profession}

Today's sports literature is full of quotes, statements by elite athletes and coaches who are unique in their attitude that sport is $50-90 \%$ mental activity, that it is played with the body, and won with the mind, and that high-quality physical, technical and tactical preparation is not solely sufficient for toplevel sports achievements. This is best confirmed by the words of the famous boxer M. Ali and athlete J. Owens: "The champions are not made in the gym. The champions are made from something that is deep down in themselves - desires, dreams and visions. They must have the skills and the will. But the will must be stronger than the skill"; "We all have dreams, but in order to achieve them we need a lot of determination, dedication, self-discipline and effort". These and similar statements directly point to the importance of psychological factors in sports, and the sports psychology is dedicated precisely to these factors. It is therefore not surprising that an increasing number of athletes and sports teams (clubs and national teams), both in the world and in our country, have their own sport psychologists who help them improve performance, achieve the most when it is the hardest - against the strongest rivals and the biggest competitions. With this assertion, the first dilemma was posed and the answer to the question is given, what the sport and exercise psychology is, and what psychologists of sport and exercise do.

It is difficult to give a comprehensive definition of the sports psychology, not only because of its inter and multidisciplinary nature (it connects various psychological subdisciplines with sports and exercise science, other social and humanistic doctrines and medicine), but also because of the fact that it means different things for different people (Bačanac, 2010). It is most often defined through the subject of study or activity of sport psychologists, or as a study of psychological or mental factors that influence and / or are influenced by sports or physical exercise. The European Association for Sports psychology in its starting points emphasizes that it deals with the psychological aspects of sports, physical exercise / recreation and physical education (FEPSAC, 2011), and it defines it as the study of psychological founda- 
tions, processes and consequences of sport (FEPSAC, 1995). Section 47 of the American Psychological Association defines sport and exercise psychology as a scientific research of psychological factors related to participation and performance in sports, exercise and other types of physical activity (APA Division -47 , 2009). The above and many other definitions - as well as the Cox's, which says that sports psychology is a science that applies psychological principles in the field of sports and exercise (Cox, 2012, p. 5) - accentuate what sport psychologists research, i.e. what the academic sports psychology deals with the most, and not what psychologists do in immediate practice.

The definition of the American Association for Applied Sports psychology (AASP) emphasizes these problems: the applied sport and exercise psychology involves the extension of theories and research to the training of sports coaches, athletes, parents, practitioners and fitness experts on the psychological aspects of their sport or activity. The primary goal of professionals of applied sport and exercise psychology is to facilitate / encourage optimum involvement, exercise and enjoyment of sports and exercise (AASP, 2018).

Perhaps this discussion of the subject of sport and exercise psychology is best concluded by the attitude of most contemporary sport psychologists who emphasize that it relates to two broad areas: (1) the study of the impact of psychological and emotional factors on sport and exercise, and (2) the study of the impact of dealing sports and exercise on psychological and emotional factors (Cox, 2012). Weinberg and Gould (2011) point out that sport and exercise psychology represents a scientific study of people and their behaviour in sports and exercise activities and the practical application of this knowledge. Psychologists of sport and exercise have two tasks: (a) to understand how psychological factors affect performance in sport and exercise; and (b) to understand how sport and exercise contribute to the development, health, welfare and well-being of persons.

\section{Sports psychology in the World}

Seldom there is a sports psychology textbook that does not list the names of significant psychologists who have permanently marked the emergence of this applied psychological science, its characteristic development in certain periods of time, contributed to the emergence of numerous professional associations and organizations, specialized journals and paved the way for future trends in its development (Cox, 2012; Keegan, 2016; Lavallee, Kremer and Moran, 2008; Le Unes and Nation, 1999; Moran, 2004; Singer, Hausenblas and Janelle, 2001; Tod, Thatcher and Rahman, 2010; Weinberg and Gould, 2011; Williams and Straub, 2010).

Although the emergence of sports psychology is connected to the late $19^{\text {th }}$ and early $20^{\text {th }}$ century when Norman Triplett carried out the first socio-psychological experiment in 1898 and found that cyclists drive faster in the presence of others than when driving alone, its emergence as an independent scientific psychological discipline occurred in the $60 \mathrm{~s}$ and $70 \mathrm{~s}$ of the 20th century. The triplet experiment served as an inspiration to Zajonc in 1965 to postulate the theory of social facilitation that best explains how sports play is influenced by the presence of the audience, why there is the advantage of the home court, why there is the "choking under pressure" when in sports team there comes the concept of "social goofing around" and how the team cohesion influences the competitive achievement.

When they talk about the history of sports psychology, Weinberg and Gould (2011) divide it into six characteristic periods; Singer (2001) lists five, and Cox (2012) and other authors (e.g. Lavalee et al., 2004; Keegan, 2016; Moran, 2004) do this by stating the names of psychologists who, with their contributions in the field of research and / or practice, marked certain periods of its faster or slower development.

With no intention of getting into more details of all important people and dates relevant to the development of sport and exercise psychology, there follows a brief overview of six characteristic periods of its history in the United States, as well as key dates and personalities that marked the history of Sports psychology (PS) in Europe. It has already been said that Triplett marked the first period or "Early Years" as Weinberg and Gould (2011) called it. This period began in 1893 and ended in 1920, and the Triplet was marked by Scripture with studying the speed of reaction and movement and the description of the personality traits that he believed could be fostered through sport, and by Patrick with his discusses about the psychology of the game.

The second period or "the Griffith's era" (19211938) was marked by psychologist Coleman Griffith, whom was called the father of American sports psychology. He devoted most of his scientific career to 
the sports psychology, published 25 research papers in this field and wrote two classical books: Psychology of Training (1926) and Sports psychology (1928). In addition, he was the initiator of one of the first coaching schools in America, and in 1925 he founded the Laboratory for Research in Sport at the University of Illinois.

Weinberg and Gould (2011) called the third period (1939-1965) "Preparation for the Future", and it was marked by the work of Henry Franklin of the University of Berkeley who first dealt with the psychological aspects of motor sporting skills, developed the physical activities psychology program intended for students of physical education and educated a large number of prominent experts in the domain of kinesiology. This period was marked by Dorothy Yates by working with boxers in colleges and exploring the effects of relaxation training; Warren Johnson, who evaluated pre-contesting emotions among athletes and John Lawther, who wrote Psychology of Coaching. The year 1965 and the city of Rome are the most important date and place in the history of sports psychology, since the first professional organization of sport psychologists - the International Association for Sports psychology (ISSP) was founded and the first international congress of sport psychologists was held at that time.

The fourth period (1966-1977) is characteristic because of the founding of sports psychology as an academic discipline different from motor learning, with a wide range of research topics and practical work with athletes and teams first started by Bruce Ogilvie, called the father applied the sports psychology in North America. In 1966, together with Thomas Tutko he wrote the well-known book "Problem of Athletes and How to Work with Them". In that period, more precisely, in 1967, the first North American Sports psychology and Physical Activity Association (NASPSPA) was founded, and in 1970 the first journal of the International Journal of Sports psychology was published. The most important names of this period are Bryan Cratty and his book "Psychology of Physical Activity", as well as Robert Singer with the book Motor Learning and Human Performance.

The fifth period (1978-2000) called "Multidisciplinary Science and Practice in Sport and Exercise Psychology" is characterized by a huge increase in research, growing number of practicing psychologists, creation of new professional organizations, conferences and congresses held, the emergence of special- ized journals and books. It is difficult to distinguish individuals and events that marked it, but Dorothy Harris should certainly be mentioned, who was rightly referred to as "the mother of sports psychology" for her contributions. The first issues of the magazines Journal of Sports psychology (1979, now Journal of Sport and Exercise Psychology), Sport Psychologist (1986), Journal of Applied Sports psychology (1989), as well as the establishment of two important organizations: Improvement of Applied Sports psychology Association (AAASP, 1986) and Division 47 of the American Psychological Association (APA Division-47, 1986), which covers the field of psychology of exercise and sports (About Div. 47).

The sixth period from 2001 to the present is called by Weinberg and Gould the period of contemporary sport and exercise psychology that constantly progresses, expands and improves methods of scientific research and practical work. Among many sports and exercise psychologists who deserve to be named, Rainer Martens, the former professor of sports psychology at the University of Illinois, founder of the largest publishing house in the field of sports, Human Kinetics Publishers, and the author of an unprecedented manual for the American Sports Education Program (ACEP) Successful training (1990...2012).

Parallel to the development of sports psychology in America, there is also its development in $\mathrm{Eu}-$ rope. It is linked to the name of Pierre de Coubertin, President of the International Olympic Committee (IOC), from 1896 to 1925 , who first introduced the term sports psychology (Cox, 2012). He organized two Olympic congresses (1897 in France and 1913 in Switzerland) with topics in sports psychology, while at the congress in Switzerland (Lausanne) the formal sports psychology was designated as a new discipline within sports science for the first time, so that this year is considered the birthday of this science in Europe in the opinion of de Coubertin, the father of European sports psychology. European sport psychologists, especially the Soviet, German and Czech, are beginning to seriously deal with the problems of sports psychology at the same time as Coleman Griffith in America (Bačanac, 2015). The first sports psychology laboratory was founded by Carl Diem in the German sports school in Berlin in 1920. Only five years later (1925) Puni opened a sports psychological laboratory at the Institute of Physical Culture in Leningrad, and the Department of Sports psychology was opened in 1930. His colleague Rudik founded the first sports- 
psychological laboratory in the Soviet Union at the Institute of Physical Culture in Moscow in 1925. It is important to note that in the late 60s and early 70s of the 20th century, Puni developed and published his model of "Psychological preparations for the competition", at a time when American sport psychologists were more focused on sports science than on the applied sports psychology (Cox, 2012).

The man who devoted most of his life to the sports psychology was the Italian Ferruccio Antonelli. He organized the First International Congress of Sport psychologists in Rome in 1965, on which the International Association of Sports psychology (ISSP) was founded, which linked sport psychologists around the world (Cei, 2011). Five years later, in 1970, Antonelli launched the first scientific journal entirety dedicated to the sports psychology International Journal of Sports psychology (now International Journal of Sport and Exercise Psychology). In addition to the aforementioned Soviet psychologists Puni, Rudik and Rodionov, a great contribution to the development of sports psychology and its application in practice has been given by numerous British, Czech, German, Bulgarian and Swiss sport psychologists, such as Vanek, Hosek, Svoboda, Macak, Giza, P. Kunat, E. Geron, F. Genov, E. Apich, Shilling and others. The great incentive for further development and improvement of the European sports psychology was the establishment of the European Federation of Sports psychology (FEPSAC) in 1968, by establishing the practice of the regular European Congress of Sport psychologists (since 1969) and the launch of the journal Sport and exercise psychology (1970) which belongs to the category of the most influential and most prestigious scientific journals in a wide field of sport and exercise psychology.

\section{SPORTS PSYCHOLOGY IN SERBIA - YESTERDAY AND TODAY}

We will follow the history of sports psychology in Serbia through its development in professional, teaching and scientific institutions in the field of sports and through important events and publications of domestic authors dedicated to its topics and contents, intended for sports professionals and students of sports science. Bačanac (2015) considers that the history of sports psychology in the former SFRY (Socialist Fed- eral Republic of Yugoslavia), and therefore Republic of Serbia of today, at that time, one of its 6 constituent units is linked to the Yugoslav Institute for Physical Culture and Medicine of Sport (JZFKMS). It was founded in 1956 as the first professional and scientific institution with the aim of improving all segments of physical culture (sports, recreation, physical education) in the entire territory of Yugoslavia of these days. Six years later, i.e. in 1962, JZFKMS became the first institution in the field of sports, both in the former SFRY and in Serbia, where the Laboratory for Sports psychology was established for the purposes of sports theory and practice.

With the diploma of a psychologist and experience acquired through her own athletic career, Mirjana Dragićević started applying general psychological knowledge to sports, dealing with psychological diagnostics, counselling and psychological preparation of athletes. In 1974 the psychologist Ljubiša Lazarević (with his personal sports experience in football) came into her place, and continued the practice, working on further improvement of the methodology of psychological assessment of athletes and started the first research of motivation for going for sports and determining the specificity of personality profiles, motivation of achievements and cognitive abilities of athletes of different levels of success. He was the first sport psychologist who became an official member and professional consultant of our athletes at the Olympic Games in Montreal (1976), Moscow (1980) and Los Angeles (1984). Due to the enormous contribution to the development and improvement of applied and academic sports psychology (he wrote important textbooks and handbooks for students of sports science and practicing psychologists - see Tables 1 and 2), he can rightly be called the father of Serbian sports psychology. In 1976 Ljubica Bačanac came to JZFKMS, who was engaged in the applied sports psychology, research work and education of trainers, athletes, parents of athletes and other participants in sports for 36 years. Nevertheless, she devoted most of her attention to the advancement of the children's and youth sports, in an effort to promote its educational and social values, to highlight its important role in comprehensive bio-psycho-social development and health, to reduce all forms of accompanying violence and inappropriate behaviour, thus allowing children and young athletes make sport more beautiful and healthier. Several psychologists tried and stayed, for a shorter or longer period of time, in roles of sport 
psychologists permanently employed in this institution (Vesković A., Nikolić M., Ilić J.). The joint work of Lazarevic and Bačanac in the seventies and eighties of the last century resulted in the establishment of close cooperation between trainers and athletes on one and sport psychologists on the other side. Sport psychologists have become permanent members of professional teams of all successful sports associations in former Yugoslavia and present Serbia, and their services are available to all interested users.

Along with the development of sports psychology in JZFKMS, now the Serbian Institute for Sport and Sports Medicine, the sports psychology fought and won for its place in the curriculum of the Faculty of Sport and Physical Education in Belgrade. Although this higher education institution was founded in 1946 as the State Institute for Physical Culture, sports psychology began to be studied there as an independent and obligatory teaching subject, and not as a part of general psychology and motor control, from 2000 until 2012 when, unfortunately, it got the status of an elective teaching subject. In addition to the important topics in the sports psychology, students of sports and physical education acquire specific psychological knowledge through several other subjects, such as general psychology, developmental psychology, motor control, children's sports, women and sport. In this way, they get a solid basis to perform their professional activities in the role of teachers of physical education, sports trainers, practitioners and experts in all other aspects of physical activity (fitness, recreation), with more competence and self-confidence.

Table 1 Chronology of development of sports psychology in Serbia (taken and edited according to Bačanac, 2009, 2015)

\begin{tabular}{|c|c|c|}
\hline Year & $\begin{array}{l}\text { Events important for the development of national } \\
\text { sports psychology }\end{array}$ & Sports psychology in higher education institutions \\
\hline 1953 & $\begin{array}{l}\text { Sports Institute of Vojvodina was founded; it changed } \\
\text { the name and founders several times (nowadays: The } \\
\text { Regional Institute of Sport and Sports Medicine). }\end{array}$ & $\begin{array}{l}\text { The State Institute for Physical } \\
\text { Culture, DIF (nowadays the }\end{array}$ \\
\hline 1956 & $\begin{array}{l}\text { Yugoslav Institute for Physical Culture and Sports } \\
\text { Medicine (JZFK) was founded (nowadays: Serbian } \\
\text { Institute of Sport and Sports Medicine) }\end{array}$ & $\begin{array}{l}\text { Faculty of Sport and Physical } \\
\text { Education - FSFV) }\end{array}$ \\
\hline 1962 & $\begin{array}{l}\text { JZFK employed the first psychologist with the task } \\
\text { to deal with problems of sports psychology and to } \\
\text { confront the growing problems of sports practice. }\end{array}$ & $\begin{array}{l}\text { Since the foundation of FSFV until } 2000 \text {, Sports } \\
\text { psychology was studied within the subject "Psychology". }\end{array}$ \\
\hline 1975 & $\begin{array}{l}\text { There are two sport psychologists working in JZFK } \\
\text { and that number remains the same till 2010. Nowadays } \\
\text { there are three indefinite-time employed sport } \\
\text { psychologists in the Republic Institute of Sport and } 1 \\
\text { or more volunteers, graduated psychologists. }\end{array}$ & $\begin{array}{l}\text { Sports psychology is studied } \\
\text { as a separate and compulsory } \\
\text { subject at the Department of } \\
\text { Sport. }\end{array}$ \\
\hline 1975 & $\begin{array}{l}\text { - Paranosić, V., Lazarević, Lj.: Psihodinamika sportske } \\
\text { grupe. [Psychodynamics of a sports group]. Beograd: } \\
\text { Savez za fizičku kulturu Jugoslavije. }\end{array}$ & $\begin{array}{l}\text { The first book published from the field of sports } \\
\text { psychology }\end{array}$ \\
\hline
\end{tabular}




\begin{tabular}{|c|c|c|}
\hline 1981. & $\begin{array}{l}\text { - } \text { Havelka, N., Lazarević, Lj.: Sport i ličnost. [Sport and } \\
\text { personality]. Beograd: Sportska knjiga. }\end{array}$ & \multirow{13}{*}{$\begin{array}{l}\text { Psychological education of the future experts in sport } \\
\text { and PE teachers, apart from the curriculum of the subject } \\
\text { Sports psychology is also realized through curricula of } \\
\text { the following subjects: } \\
\text { 1. General psychology } \\
\text { 2. Children's sport - Psychological and } \\
\text { pedagogical aspects of work with children } \\
\text { 3. Motor control - Psychological aspects of } \\
\text { learning and performing motor skills } \\
\text { 4. Developmental and pedagogical psychology } \\
\text { 5. Women and sport - Sport in the function of } \\
\text { the psychical health of a woman }\end{array}$} \\
\hline 1982 & $\begin{array}{l}\text { - Mladenović, U.: Osnove psihologije sporta.[ Basics } \\
\text { of sports psychology]. Novi Sad: Zavod za fizičku } \\
\text { kulturu Vojvodine. }\end{array}$ & \\
\hline 1987 & $\begin{array}{l}\text { - Paranosić, V.: Psihologija sporta. [Psychology of } \\
\text { sport]. Beograd: Nip Partizan. }\end{array}$ & \\
\hline 1994 & $\begin{array}{l}\text { - Lazarević, Lj.: Psihološke osnove fizičke kulture. } \\
\text { [Psychological basis of physical culture]. Beograd: } \\
\text { Viša škola za sportske trenere. Dopunjeno izdanje } \\
\text { 2001. }\end{array}$ & \\
\hline 1996 & $\begin{array}{l}\text { Lazarević: Psihološka priprema sportista. } \\
\text { [Psychological preparation of athletes]. Beograd: } \\
\text { Viša škola za sportske trenere. Dopunjeno izdanje } \\
2003 .\end{array}$ & \\
\hline 2003 & $\begin{array}{l}\text { - Dunđerović, R.: Psihologija sporta. [Psychology of } \\
\text { sport]. Novi Sad: Fakultet fizičke kulture }\end{array}$ & \\
\hline 2004 & $\begin{array}{l}\text { - Pajević, D.: Psihologija sporta i rekreacije. [Psychology } \\
\text { of sport and recreation]. Laktaši: Grafomark }\end{array}$ & \\
\hline 2004 & $\begin{array}{l}\text { - Bačanac, Lj.: Psihološki aspekti orijentiringa. } \\
\text { [Psychological Aspects of Orientation]. Niš, „Krug”: } \\
\text { Savez za orijentacioni sport Beograda. }\end{array}$ & \\
\hline 2005 & $\begin{array}{l}\text { - Bačanac, Lj.: „Motorne veštine - psihološki pristup”[ } \\
\text { Motor skills - a psychological approach]. Skripta za } \\
\text { studente sporta (više puta dopunjavana, poslednji put } \\
\text { 2017.) }\end{array}$ & \\
\hline 2005 & $\begin{array}{l}\text { - Bačanac, Lj.: Elementi psihologije sporta"[ Elements } \\
\text { of Sport Psychology]. Skripta za internu upotrebu; } \\
\text { (poslednji put dopunjena 2015.). }\end{array}$ & \\
\hline 2007 & $\begin{array}{l}\text { - Bačanac, Lj., Radovanović, I.: Vaspitanje kroz sport. } \\
\text { [Education through sports]. Beograd: Učiteljski } \\
\text { fakultet. }\end{array}$ & \\
\hline 2008 & $\begin{array}{l}\text { - Bačanac, Lj., Škof, B. (2007). Vzgojne naloge in } \\
\text { ravnanja učiteljev/trenerjev pri delu } z \text { mladimi v } \\
\text { športu. [Educational tasks and behavior of teachers / } \\
\text { trainers in working with young people in sports]. U } \\
\text { B. Škof (Ur.), Šport po meri otrok in mladostnikov (str. } \\
\text { 88-112), Ljubljana: Fakulteta za šport. }\end{array}$ & \\
\hline 2009 & $\begin{array}{l}\text { - Pokrajac, B.: Psihologija sporta. [Psychology of } \\
\text { sport]. Beograd: Visoka škola strukovnih studija } \\
\text { "Akademija fudbala" }\end{array}$ & \\
\hline 2010 & $\begin{array}{l}\text { The Regional Institute of Sport employed a sport } \\
\text { psychologist for the first time }\end{array}$ & $\begin{array}{l}\text { Sports psychology became } \\
\text { an elective subject. }\end{array}$ \\
\hline
\end{tabular}




\begin{tabular}{|c|c|c|}
\hline 2011 & $\begin{array}{l}\text { - Bačanac, Lj., Petrović, N., Manojlovič, N.: Psihološke } \\
\text { osnove treniranja mladih sportista. [Psychological } \\
\text { basis of training of young athletes]. Beograd: } \\
\text { Republički zavod za sport }\end{array}$ & \multirow{7}{*}{$\begin{array}{l}\text { Within a large number of colleges of further education } \\
\text { and faculties dealing with the education of personnel } \\
\text { in the field of sports and physical education, located } \\
\text { in Belgrade, Niš, N. Sad, Leposavić, N. Pazar, sport } \\
\text { psychologists deal with academic psychology of sports, } \\
\text { i.e. education of students the future experts in the field } \\
\text { of sports, exercise and physical education, and only rare } \\
\text { individuals do practical work with athletes. }\end{array}$} \\
\hline 2012 & $\begin{array}{l}\text { - Havelka, N., Lazarević, Lj.: Psihologija menadžmenta u } \\
\text { sportu. [Psychology of sport management]. Beograd: } \\
\text { Visoka sportska i zdravstvena škola. }\end{array}$ & \\
\hline 2015 & $\begin{array}{l}\text { - The first association of SP "The Section for Sports } \\
\text { psychology" was founded in Belgrade within the } \\
\text { Serbian Psychological Society. There were } 22 \text { SP. } \\
\text { Unfortunately, it was active for a short period of time, } \\
\text { its activities ceased after a year. }\end{array}$ & \\
\hline 2016 & $\begin{array}{l}\text { - Bačanac, Lj.: Agresivnost } i \text { nasilje u sportu. } \\
\text { [Aggression and violence in sports]. Beograd: Zavod } \\
\text { za udžbenike. }\end{array}$ & \\
\hline 2017 & $\begin{array}{l}\text { - Bačanac, Lj., Petrović, N., Manojlović, N.: Sport } i \\
\text { nasilje: Empirijska analiza nasilja u sportu Srbije. } \\
\text { [Sport and Violence: An Empirical Analysis of } \\
\text { Violence in Sports in Serbia]. Beograd: Sportski savez } \\
\text { Srbije. }\end{array}$ & \\
\hline 2017 & $\begin{array}{l}\text { - Bačanac, Lj., Škof, B. (2016). Pedagoški in psiho- } \\
\text { socialni vidiki športa mladih. [Pedagogical and } \\
\text { psycho-social aspects of youth sports]. U B. Škof i N. } \\
\text { Bratina (Ur.), Šport po meri otrok in mladostnikov. } 2 \text {. } \\
\text { dopolnjena izdaja (str. 128-271). Ljubljana: Fakulteta } \\
\text { za šport. }\end{array}$ & \\
\hline 2018 & $\begin{array}{l}\text { - Vesković, A.: Psihologija sporta: Odabrane teme. } \\
\text { [Psychology of Sport: Selected Topics]. Beograd: } \\
\text { Fakultet sporta i fizičkog vaspitanja. } \\
\text { - Vesković, A.: Psihologija vežbanja: Odabrane teme. } \\
\text { [Psychology of Exercise: Selected Topics]. Beograd: } \\
\text { Fakultet sporta i fizičkog vaspitanja. }\end{array}$ & \\
\hline
\end{tabular}

The key moments in the development of the sports psychology in Serbia can be mentioned by specifying important dates regarding its origin, persons who marked certain periods, sporting events in which sport psychologists were involved in providing professional assistance to athletes and trainers and significant publications from the domain of sport and exercise psychology. Such data are summarized in Table 1, while Table 2 contains facts for analysing the comparative development of the sports psychology in Serbia with its development in other countries (the USA and Europe). If the data from Table 2 are carefully analysed, it appears that the sports psychology in Serbia appears as an independent scientific and applied psychological discipline at the same time when in the world, even earlier, if the year of employment of the first full-time sport psychologist is taken as the criterion of its actual recognition and affirmation in the family of sports sciences, and that was in 1962, much earlier than, for example, in the United States (1985, according to Weinberg and Gould, 2011). It is similar with the engagement of sport psychologists at major world competitions. Sport psychologist Ljubiša Lazarević was officially in the Yugoslav Olympic team at the Mediterranean Games in Algeria in 1975, and then at the Olympic Games in Montreal in 1976 and in Moscow in 1980, while sport psychologists in the United States officially became part of the Olympic teams as early as 1984 (Bull, 2009), while according to other sources this happened in 1987 (McKann, 2005) and 1988 (Kremer and Moran, 2008). 
Table 2 Comparative display of key moments in the development of sports psychology in Serbia and the world

\begin{tabular}{|c|c|c|}
\hline Year & Serbia & World \\
\hline 1956 & $\begin{array}{l}\text { JZFKMS was founded in Belgrade (Nowadays: } \\
\text { Serbian Institute of Sport and Sports Medicine) }\end{array}$ & \multirow{2}{*}{$\begin{array}{l}\text { - 1965: ISSP- International Society of Sports } \\
\text { psychology was founded in Rome } \\
\text { - The first world congress of sport psychologists }\end{array}$} \\
\hline $1962: 1 \mathrm{C \Pi}$ & $\begin{array}{l}\text { JZFKMS employed the first psychologist dealing } \\
\text { with problems of sports psychology }\end{array}$ & \\
\hline $1975: 2$ SP & \multicolumn{2}{|c|}{$\begin{array}{l}\text { JZFKMS employed another } 1 \text { SP. For as long as } 35 \text { years, two (2) SP had been trying to satisfy the ever- } \\
\text { growing needs of Yugoslav and later Serbian sport. }\end{array}$} \\
\hline 1975 & $\begin{array}{l}\text { For the first time, the Yugoslav Olympic } \\
\text { Committee officially included a SP from } \\
\text { JZFKMS into the professional team for providing } \\
\text { medical and psychological support to athletes } \\
\text { during Mediterranean Games in Algeria. }\end{array}$ & \multirow{2}{*}{$\begin{array}{l}\text { - in } 1968 \text { at the OG in Mexico, SP M. Vanek was } \\
\text { included into the Czechoslovakian OT; } \\
\text { - since } 1960 \text { and the OG in Melbourne, SP is in the } \\
\text { OT of Eastern European Countries; } \\
\text { - since } 1970 \text { athletes of the East Germany and the } \\
\text { Soviet Union have regularly used the services of the } \\
\text { SP; } \\
\text { - in } 1976 \text { the American Olympic team had an SP for } \\
\text { the OG in Montreal for the first time. }\end{array}$} \\
\hline 1976 & $\begin{array}{l}\text { A SP from JZFKMS was a part of the Olympic } \\
\text { team at the OG in Montreal. }\end{array}$ & \\
\hline 1979 & $\begin{array}{l}\text { In the expert team for the Mediterranean games } \\
\text { in Split, there are } 2 \text { SP from JZFKMS available to } \\
\text { athletes throughout the whole competition. }\end{array}$ & $\begin{array}{l}\text { - in } 1980 \text { the Olympic Committee of the USA formed } \\
\text { the Advisory board for sports psychology. } \\
\text { - in } 1985 \text { OK of the USA employed full time SP for } \\
\text { the first time } \\
\text { - in } 1988 \text { the Olympic team of the USA was officially } \\
\text { followed by respected sport psychologists }\end{array}$ \\
\hline 1980 & $\begin{array}{l}\text { Within the OT of the SFRY at the OG in Moscow, } \\
\text { there is } 1 \text { SP from JZFKMS. }\end{array}$ & \multirow{2}{*}{$\begin{array}{l}\text { - Since } 1984 \text { services of the SP were regularly used } \\
\text { by the American athletes, participants of the } \\
\text { summer and winter OG; } \\
\text { - In the OK of the USA, there were } 4 \text { full time SP: } 3 \\
\text { in the Olympic train centre in Colorado Springs } \\
\text { and } 1 \text { in San Diego. }\end{array}$} \\
\hline 1984 & $\begin{array}{l}\text { Within the OT of the SFRY at the OG in Los } \\
\text { Angeles, there is } 1 \text { SP from JZFKMS. }\end{array}$ & \\
\hline 2009 & \multicolumn{2}{|c|}{ Within the team of the OKS at the EYOF in Tampere (Finland) there is 1 SP from RZS. } \\
\hline 2010: 3 SP & \multicolumn{2}{|c|}{$\begin{array}{l}\text { Because of the growing need of sports practice, the RZS employed another one SP, so that there was the } \\
\text { total of } 3 \text { of them. }\end{array}$} \\
\hline 2011 & \multicolumn{2}{|c|}{ Within the team of the OKS at the EYOF in Trabzon (Turkey) there was 1 SP from the RZS. } \\
\hline $\begin{array}{l}\text { 2011: } \\
4 \text { SP }\end{array}$ & \multicolumn{2}{|c|}{$\begin{array}{l}\text { Serbian Institute for Sport and Sports Medicine employed another one SP, because the Laboratory for } \\
\text { Sports psychology gradually expanded the framework of its research and professional activity. From } 2011 \\
\text { to } 2013 \text {, there are } 4 \text { permanently employed sport psychologists in the RZS. }\end{array}$} \\
\hline 2012 & \multicolumn{2}{|c|}{ Within the OKS team at the OG in London, there was 1 SP from the ZSMSRS. } \\
\hline 2013: 3 SP & \multicolumn{2}{|c|}{ In the ZSMSRS there were 3 permanently employed SP and one with the employment contract. } \\
\hline 2014: 1 SP & \multicolumn{2}{|c|}{$\begin{array}{l}2 \text { SP left ZSMSRS and at the end of the year there was only one permanently employed and one engaged by } \\
\text { contract. Such state remained till the beginning of } 2018 \text { when the number of permanently employed raised } \\
\text { to } 2 \text { SP. }\end{array}$} \\
\hline 2018: 2 SP & \multicolumn{2}{|c|}{$\begin{array}{l}\text { At the beginning of the year, the Institute employed another } 1 \text { SP, so that there are currently } 2 \text { permanently } \\
\text { employed SP in this Republic, professional and scientific institution. }\end{array}$} \\
\hline Note & \multicolumn{2}{|c|}{ In the work of the Institute so far, more than 19,000 athletes have been tested! } \\
\hline
\end{tabular}

ABBREVIATIONS: JZFKMS - Yugoslav Institute for Psychical Culture and Sports Medicine; SP - sport psychologist; PS- sports psychology; SFRY - the Socialist Federal Republic of Yugoslavia; OK- the Olympic Committee; OT- Olympic team; USA - the United States of America; RZS - Republic Institute of Sport; ZSMSRS - Serbian Institute of Sport and Sports Medicine - the heir of RZS. OKS - the Olympic Committee of Serbia. EYOF - European Youth Olympic Festival 
If the time of origination of the first significant publications from the field of sports psychology is taken as a criterion for comparative analysis, then it can be concluded (Table 1) that Serbia is late compared to "the world" because the first domestic publication of the Psychodynamics of the sports group was published in 1975, while Coleman and Griffith published their Psychology of Coaching and Psychology of Athletics in 1926 and 1928 respectfully, and since then, in the United States, new books, handbooks, monographs and textbooks have been published continuously, which together with specialized magazines make it possible that theoretical and practical knowledge in Sports psychology reach all interested users. Nevertheless, in the early 1980s, and especially since the 2000s, there has been a noticeable increase in domestic publications as a result of the growing activity of academic sport psychologists, but also significant scientific research projects by practicing psychologists driven by the need to make the obtained knowledge available to all sports science and practice experts, especially to sport psychologists.

The data presented in Table 2 show that by the end of 2012 there was a trend of growth in the number of indefinite-term full-time employed psychologists at the Sports Institute in Belgrade, after which their number is significantly reduced to only two qualified sport psychologists nowadays. At the same time, this trend of reducing the number of sport psychologists in sports institutions is followed by their presence in the free market. Numerous individuals who call themselves sport psychologists offer their services within personal private practice without having any information about their qualifications for that job. Of course, this is followed by the absence of a national association for the sports psychology with all the attributes that such associations bring and contribute to the development of the profession.

From Tables 1 and 2 it is clearly noticed that the development of domestic sports psychology has been parallel to those in educational institutions (faculties of sports and physical education) and professional institutions, such as institutes or institutes of sport (JZFKMS, Serbian Institute of Sport and Sports Medicine - RZS, Regional Institute of Sport and Sports Medicine). At one time, it was more visible and more intense in professional sports institutions, and sometimes in the academic. Since sport psychologists are traditionally academically or practically oriented (Kontos and Feltz, 2008) and some of them combine both roles in their work, it is interesting that in the former SFRY, and since 2006 in Serbia as in the independent state, psychologists involved in applied psychology, after a certain experience acquired in practice, accept the role of academic psychologists and very often unify and practice both roles, both applied and academic ones. The opposite way, that academic sport psychologists are engaged in immediate sports practice after a certain period of time, as far as we know, is not recorded in our country, although in the world such practice exists. Likewise, there is still a considerable discrepancy between theory and practice, that is, between academically and practically oriented sport psychologists, but this gap is constantly decreasing. Because, as most of our experienced and qualified sport psychologists simultaneously perform both roles, it cannot be said that only academic sport psychologists focus on scientific research and education, and practitioners only to practical work with participants in sports. This claim is based on the fact that some of the most significant fundamental research in the domain of sports psychology was initiated by practicing psychologists and realized in professional sports institutions. Good examples are studies of characteristics of the personality and motivation of athletes of different levels of success, which was carried out at the Institute of Sport in the late 1970s, or the research of the types and levels of violence in the sport of Serbia, as well as psycho-social and situational factors that stimulate it, also derived from the same professional institution during 2008.

\section{Psychologists and staff for the position of a sport psychologist}

When it comes to the characteristics of the development of the sports psychology in Serbia, there is logically imposed question how it looked like at its beginnings, as later, when it became fully recognized and accepted by all participants in sports, and today, when our academic, and especially sports practice is full of psychologists dealing with various problems and topics, from individuals who, rightly or without any reference, call themselves sport psychologists, mental trainers or trainers of psychological skills. In the early phase linked to the period from 1962 to the early 1980s, domestic sports psychology has crossed a long way in which it has grown up as an independent scientific discipline trying to come up with authentic methods, specific theories, measures and assessment 
tests (psychological profiling of athletes), models of psychological preparation, methods of psychological counselling and programs for improving performance. It should be said that at that time and unfortunately today, there was no official system or training program for sport psychologists at the faculties of psychology, but rarely did graduated psychologists, guided solely by their own interest and love towards sports, determine that the acquired psychological knowledge, supported by personal sports experiences, transfer to sports practice so that individual athletes and sports teams (from club to national teams) help overcome the numerous psychological barriers that prevent them from realizing their sports potentials. They quickly realized that the existing psychological tests and theories that have been inherited from general or clinical psychology and are aimed at the general population or people with psychological disorders are neither adequate nor sufficient for the psychological assessment of the sports and exercise population, that they must rely on knowledge from other sports sciences in their work, that their counselling and therapeutic work differs considerably from that which takes place in traditional psychotherapeutic circumstances, both in the places, contexts and conditions in which it takes place, and in ethical issues and dilemmas they face. Such and similar questions had to be solved by relying on the knowledge of the psychological science and practice of the developed countries, and in particular this was important in the domain of psychological diagnostics, psychological preparation and mental skills training.

\section{From methodological adaptation to interactive approach in the process of learning}

Domestic sport psychologists have continuously monitored modern achievements in their science, translated and adapted new psychological tests made specifically for athletes and those who exercise, tests that took into account the characteristics of specific sporting situations on the one hand and characteristics of the athlete's traits, condition or mood on the other, in order to better understand and anticipate their behavior. At the end of the 1970s, our sports practicing psychologists, in the process of psychological diagnostics, i.e. determining the current psychological status (relevant psychological characteristics, traits and conditions, advantages and disadvantages, potential problems in competitive performance, team relations, communication with teammates and the coach etc.) as the basis for all other aspects of their activity (Bačanac, 2010), completely reoriented on situation-specific tests, i.e. they adopted an interaction approach. This means that they no longer evaluated pathological concurrent factors such as general anxiety, compulsiveness, phobia, hysteria, hypochondria, depression, hypnosis, psychotics, etc., but they used personality inventories for the normal population (eg Eysenck's questionnaires JEPQ, EPQ, Cattell inventory HSPQ and 16 PF, inventory of Costa and McCrea NEO-PI-R, Lee and Ashton's HEXACO-PI$\mathrm{R}$ etc.), as well as a large number of new tests for assessing traits and conditions specific to sports, such as tests: traits and states of competitive anxiety (SCAT, SAS, CSAI-2), sports self-confidence (TSCI, SSCI), sports motivation questionnaires (AMI, MSP, PMQ, COQ, SMS-28), intrinsic motivation questionnaires (IMI), attention tests and interpersonal style, stress situations in different sports (TTAIS, RSIFT, CCBQ), ACSI Athletic Coping Stress Inventory, Emotional Control Questionnaire (EPQ), scale for measuring leadership style, cohesiveness of sports teams, motivational climate (LSS, GEQ, PMCQ), etc.

Some of these tests, like many others, originated in the period from the 1990s and after 2000, and their names speak sufficiently about the extent of the topics that contemporary sports psychology deals with today. They treat problems related to the burnout of athletes, coaches and judges, the issues of the sports identity and its measurement, the positive and negative aspects of perfectionism among athletes, assess the flow state (state of commitment in which the highest achievements are achieved), assess psychological strategies used by athletes during training and competition, attitudes towards mental training and experience in its use, use bio feedback machines for self-regulation of autonomous biological functions for the purpose of overcoming competitive chaotic stress and pressure, the perception of the coach-athlete relationship, types of the coach feedback, assess the emotions of athletes, the style of coach communication, collective efficiency, the motivational climate for young athletes, the athletes' satisfaction, measure self-leadership of athletes, competitive orientation, communication skills (e.g. listening skill), multidimensional sportsmanship orientation, etc. 


\section{Innovative part of sport psychologists in Serbia}

Apart from translating and adapting various psychological inventories of foreign authors, domestic sport psychologists, primarily employees of ZSMSRS, based on the results of their own research, personal professional experiences, current theoretical approaches to sports psychology and respect for the specifics of the domestic sports population, develop their own authentic diagnostic instruments that enable them to make their assessment of athletes as objective as possible, and further activities based on it compatible with the real needs and interests of individuals and teams to the highest degree possible. Some of them are: questionnaires for the assessment of numerous indicators of social status of young athletes, adult athletes, sports trainers, judges, fitness instructors; questionnaires for measuring the motives of sport and general achievement, the questionnaire on evaluation of importance of coaching qualifications and attributes, revised and supplemented questionnaire for assessment of competitive anxiety, questionnaires of stress situations in orienteering, sociometric questionnaires, questionnaires for measuring personally experienced violence in different actors in sports, questionnaires for assessment factors contributing to violence and measures for its prevention, questionnaires for monitoring the situation during performance, mental plans for the appearance of athletes in different sports disciplines, etc.

The mentioned activities of the practicing psychologists, as well as their continuous efforts to apply the tested methods and models in their work, to adhere to the highest standards of good practice and ethical postulates of their profession, such as competence, confidentiality, setting limits, professional, scientific and social responsibility, integrity, personal behaviour, ethics in research (APA Division-47, Policies \& Procedures, 2011; FEPSAC, Position Statement 9 , 2011). These principles are equally important for all sport psychologists, whether they are engaged in research, education or in immediate practice. However, it seems that the challenges of the applied sport psychologists are the greatest, because they often work in non-standard conditions, so ethical guidelines established by the American Psychological Association (APA) and the Serbian Psychological Society (DPS, 2000) are often inadequate, too rigid and inflexible, because they are focused on traditional psychological practice and do not take into account the specificities of complex psychological practice in the sports environment. The same is also applied in a recent study of the beliefs of students of psychology regarding the ethical behavior of sport psychologists. It has confirmed the high degree of misunderstanding of the ethical dilemmas of this profession, as well as the need to develop specific training programs from the ethics of applied sports psychology in order to minimize the inherent difficulties in their practice (Vesković and Petrović, 2017).

\section{SPORTS PSYCHOLOGY IN SERBIA - TOMORROW}

After 55 years of growing and maturing of the applied and academic sports psychology in Serbia, it can be stated that it is now an equal member of a large family of sports and psychological sciences. Since there are still individuals who neither have the right idea of what the sports psychology deals with and for whom it is intended, nor the real picture of its capabilities and limitations (some exaggerate the power of sport psychologists, others completely devalue it), it is a permanent task of sport psychologists, both academic and practitioners, to continuously educate all participants in sports about all aspects of their profession. Only in such a way shall current and future sport psychologists have the right support, assistance and understanding of trainers, parents of athletes, sports medicine experts, biomechanics, dietitians, sports officials and other direct and indirect participants in sport and exercise. It is a prerequisite for an increasing number of these professionals to be engaged in sports, that their engagement is sought and adequately evaluated.

Education is a powerful tool that can help some common prejudices, controversies and myths related to the sports psychology and sport psychologists, which exist today, but far less than, for example, in the 1970s and 1980s of the last century, to completely eradicate or at least reduce to a minimum. Even today, luckily for rare individuals, the use of sport psychologist services is a stigma, because they believe that professional support from these professionals is needed only by mentally weak athletes with more or less serious psychological problems or disorders. This is just one of a total of 32 myths that Cole and Cole listed (Cole, Cole, 2017). They state that wrong 
beliefs, prejudices and myths about the abilities and benefits of sports psychology range from those who deny and denigrate them completely, to those who glorify and unrealistically perceive (for example, the sport is a $90 \%$ mental activity, the sports psychology offers quick and easy solutions; the sports psychology can turn losers into a winner; the sports psychology takes control of athletes and puts it into the hands of sport psychologists; sports psychology can guarantee a superb performance to a sports team; sports psychology is simple hypnotizing of athletes, etc.). In addition to education, to reduce such misconceptions and myths, the most helpful is the ethical treatment of sport psychologists, the awareness of their own qualifications and the expertise and responsibility for accurate and fair presentation to clients, without exaggerating opportunities or glorifying their roles. Only with socially responsible behaviour in the best interests of their clients and in line with ethical standards of the profession, they will protect personal integrity, integrity and dignity of their profession and strengthen confidence in the sports psychology.

However, for the quality performing inter and multidimensional roles, sport psychologists must prepare well, acquire adequate education and additional knowledge both in the sports psychology, and in other areas of sports, social and humanities and medical sciences that are related to it. At the very beginning of practicing this profession in our country, it was enough that individuals only call themselves sport psychologists and start working in sports without having previously acquired any additional knowledge in the sports psychology. In the same way, without realizing the specific nature of science and practice of this discipline, the first books were written whose content consisted of topics from general, developmental and / or pedagogical psychology with only the added elements related to sports (e.g. emotions in sports, personalities of athletes, motivation in sports, anxiety and sport, etc.). Fortunately, it is no longer the case today. A new generation of psychologists emerged, some of whom underwent a serious supervised practice at the Institute of Sport and Medicine of Sport of the Republic of Serbia whose psychological laboratory from the beginning of the 1990 s to the present day was the only reference point for professional training and training of young psychologists who, either within regular student practice or as volunteers, acquired basic knowledge of all domains of their future activity. Under the supervision and guidance of experienced practitioners of psychology, they were provided with the knowledge for quality performance of the psychological assessment of athletes, became acquainted with its limitations, principles of ethics and alerted to the possible consequences of incompetent and unethical handling of the obtained data.

\section{Defining the framework of the work of a sport psychologist - from declarative and problematic to the context of comprehensive professional competence}

Sport psychologists perform a number of functions depending on where they work, which problems athletes, coaches, athletes' parents, practitioners or other participants in sports and exercise address them with, whether they are primarily educated in psychology or sports science, what their experiences in work with athletes are, whether they personally prefer work on clinical problems (anxiety, depression, eating disorders, addictive behaviours - gambling, drug abuse), or prefer consultative counselling, mental skills training, scientific research, designing programs for the efficient acquisition and application of motor skills, etc. Some sport psychologists are most engaged in improving various aspects of children's and youth sports - they train coaches and parents to provide young athletes with positive experiences in sports, develop their confidence, self-esteem, valuable social skills, strong sporting character, lasting love for sports and healthy way of life. Others are more motivated to work with top athletes and teams in order to continually manifest high competitive achievements and sport balance with other spheres of their lives.

Academically-oriented sport psychologists employed in higher education institutions, strive to transfer valuable knowledge of sports psychology to students, which they will be able to apply in their work in the future. There are more and more sport psychologists working with physically and mentally handicapped persons to whom going in for sports is not only in the function of realizing notable competitive results, but also a significant therapeutic activity, a means of re-socialization, psychological empowerment, building self-esteem and self-confidence, better quality of life and overall well-being. One should not forget the constantly growing number of sport psychologists involved in the application of psycho- 
logical principles to the promotion of physical activity in leisure time, the consequences of that activity on mental health and fitness, prescribing exercise as a means of psychotherapy and strategies for stress management, exercise barriers, theories and models of exercise behaviour, cognitive and behavioural strategies to promote intrinsic motivation for exercising and devotion to exercise, etc. The special subdiscipline of sports psychology deals with these and other problems, called the Applied Psychology of Exercise by Anshel (Anshel, 2007).

If we ask ourselves why people turn to sport psychologists for help, then in the first place there is their wish to improve their sporting performance, i.e. competitive results (Le Unes, 2011), and then learn to control the high levels of competitive anxiety, stress and pressure experienced a few days before the competition, just before the performance and during performance, which significantly diminishes the quality of their performance and prevents them from realizing the currently achieved level of sports fitness. When parents bring their children or young athletes to a sport psychologist, they most often state the following as the reason for seeking help: "You know, he / she is perfect on training, can do everything without a mistake and at a high level of quality. But, in a competition, this is a completely different person, you can not recognize him / her - he / she loses from weaker opponents, makes mistakes as a beginner, as if he / she can hardly wait for the match / game to end "; or "Coaches tell me, and so I think he / she is a great player, physically and technically at the highest level, he / she just needs his / her head "fixed" and will be unbeatable". After the first talk (exploratory interview) with an athlete, an experienced psychologist reveals a number of other problems that can be related to parent pressure, negative approach of trainers, high expectations, inability to harmonize school and sports obligations, unacceptance or unclear role in the team, high responsibility, feelings of guilt after a bad performance, fear of making a mistake, orientation to avoid failure, criticism and constant dissatisfaction from the parents, the extent and intensity of the training uncoordinated with age, favouring an individual in the team, experienced injury and fear of a new one, lack of global and sports confidence and others. Athletes also turn to sport psychologists because of the desire to restrain their emotions, to control those negative and dysfunctional, to control their own energy (to achieve the state of optimal activation or excitement, enter and maintain the best performing zone, learn the psychological skills of relaxation, concentration and imagination, to accelerate the process of recovery from injury, learn to focus, redirect and maintain attention, to better recognize the intentions, needs and motives of their teammates, learn to enjoy sports, set realistic, motivating, sufficiently challenging short-, medium- and long-term goals, work on the mental preparation for competition, etc. Sport psychologists help athletes and trainers to improve mutual communication; build a cohesive team, a climate focused on mastery and mutual cooperation; to apply different team building techniques; deal with the problems of the transition of a sports career; educate trainers to recognize the symptoms of burnout and overtraining and how to act in such situations; how to develop and maintain the motivation of athletes and team discipline; how to communicate with the parents of athletes, support staff, members of the expert team; how to use the services of sport psychologists, implement a psychological skills training program; recognize and prevent abuse of drugs for increasing performance and nutrition disorders; build their own training philosophy; be efficient leaders; how to act in crisis situations, etc.

A good picture of what sport psychologists do can be obtained by analysing the content of contemporary books, such as the Cox's Sports psychology: Concepts and Applications, 2012 with 19 thematic chapters, Foundations of Sport and Exercise Psychology by Weinberg and Gould (2011) with 24 chapters, or Applied Sports psychology by the editor J.M. Williams (Williams 2010) with 25 thematic units. An insight into the multiple and complex role of sport psychologists is also obtained on the basis of the contents of the checklist prepared by Lesyk (Lesyk, 2005) based on the APA documents, Department 47 on the Expertise of Sport psychologists, and its purpose is to assist psychologists in assessing their own knowledge and skills that are basic indicators of their expertise and the need for determining priorities in further improvement. The first list consists of specific knowledge in the field of theory and research of social, historical, cultural and developmental bases of sports psychology; principles and practice of the applied psychology involving areas and techniques of psychological assessment specific to sport, training mental skills for improving sports performance and satisfaction with sports; problems of clinical and advisory work with athletes; organizational and systemic aspects of 
sports counselling; understanding of developmental and social issues related to sports; knowledge of behavioural basics of sport and exercise (e.g. exercise psychology, motor learning, sports medicine). The second list contains 10 areas of knowledge about personalities and groups: young athletes and sports organizations; high school athletes and sports classes; athletes at faculties and sports departments; professional athletes, teams and leagues; athletes veterans and organizations; injured athletes; elite athletes and sports organizations (e.g. Olympic athletes and state administrative bodies); recreational athletes; athletes with permanent disabilities; people involved in sport but not direct participants (e.g. families, trainers, administrators, officials). The third list contains 26 specific skills that directly relate to what sport psychologists do with individuals or teams: training psychological skills for athletes; setting goals and profiling the performance of athletes; visualization and performance planning; increasing the confidence of athletes; cognitive-behavioural self-regulation techniques for athletes; training control and managing emotions; the attribution of interpretation and selfassessment in sport; nutritional disorders and weight management for athletes; drug abuse and interventions for athletes; treatment of the use of ergogenic aids / supplements for the performance of athletes; counselling athletes about grief, depression, loss, suicide; advising on overtraining and burning; genderspecific counselling; about aggression and violence in sports; sports injuries and rehabilitation; career transition and identity in sport; training (education) of team cohesion; team building; leadership training; consulting skills for sports organizations and systems; development of morale, character and sportsmanship in sport; cognitive emotional and developmental problems and the development of talent in sports; counselling on the motivation of athletes; development of self-confidence, self-esteem and competence in sports; interventions aimed at involving parents and families in children and youth sports.

And to conclude, all of the above activities of sport psychologists are performed by our psychologists, but not with the same frequency, because the demands of our athletes, trainers and parents when addressing sport psychologists are primarily related to professional help to improve sports performance, reduce high anxiety, form the right competitive orientation (to achieve success, not to avoid failure), strengthen self-confidence, learn techniques of regu- lating and managing energy, emotions, physiological and psychological activation - in a word, to reduce the gap between their real potential, the achieved level of sports form and what they show in situations of competition. Unlike the beginnings of domestic sports psychology when sport psychologists had to do mostly with the so-called "problematic athletes", today they mostly work with "good kids", young or adult athletes who want to give their maximum, be satisfied with their performance and enjoy the sport they are dealing with.

\section{Challenges of the profession and occupation of a sport psychologist}

Unfortunately, today there is a large number of self-reported sport psychologists in whose work there is a violation of the basic principles of ethics and integrity of the profession and occupation, because in a way they are deceiving their future users, they are aggressively advertised, and on different social networks they are presented as sport psychologists, while not providing any information about their own expertise and education for the profession. Such a situation is certainly contributed by the lack of professional-occupational associations, the framework of qualifications, and regulations on who is a sport psychologist, how to get education and what titles to use. Because someone who has primary education in sports science, and on master studies has acquired certain skills from a narrow field of sports psychology (for example, training various mental skills in certain sports), he cannot name and present himself as a sport psychologist. In the West and the USA, such experts are called counselors or educators in the field of sports psychology or mental trainers, and sport psychologists are persons who have acquired primary education in psychology and additional education in sports science. Sport psychologists should join together as soon as possible and organize themselves in a more effective way to solve the problems they face daily, concerning the normative regulation of their own qualifications, the establishment of a mandatory education program, supervised practice, a code of ethics, etc. This can only be done if they are organized as a section for sports psychology within the Serbian Psychological Society, which consists of more than 25 sections from different branches or areas of psychology. At the IX Congress of Psychologists of Yugoslavia in Vrnjačka Banja in 1988, an initiative 
was launched to establish an association or section of sport psychologists at the level of the State of these days. As the author of this paper remembers, they even proposed President and Secretary General of the future association, but the realization of this idea has never occurred. Many years later, more precisely in 2012, this idea was realized when the first association of sport psychologists, the Section for Sports psychology within the Serbian Psychological Society, was officially formed and registered in Belgrade. At the moment of establishment, the section had 22 members. Unfortunately, it was briefly active and after a year its activity ceased completely.

In order to better understand the current sports psychology, let us return to 1975 for a moment. That year, sport psychologist Ljubiša Lazarević officially accompanied Yugoslav athletes at the Mediterranean Games in Algeria for the first time. This work practice in the field, providing psychological assistance in large competitions, has continued till present, to say the truth, not continuously. From 1984 until 2009, sport psychologists prepared athletes for all major international performances (European Championship, World Championship, OG), but they did not go to these competitions with them. Many factors, largely unrelated to the denial of the fact that psychological support in such events is often a key component of a good competitive performance, have influenced such behavior by the most responsible individuals from sports institutions, such as the former SOFK (Association of Physical Culture Organizations), SIZ for Physical Culture (Self-Governing Interest Communities), the Ministry of Sport and the National Olympic Committee itself. The regular attendance of sport psychologists in professional bodies of the Olympic delegations was renewed in 2009 at the Summer Youth Olympic Games of Europe (EYOF) in Finland, continued in 2011 at EYOF in Trabzon, the Olympic Games 2012 in London and 2016 in Rio. We hope that our diagnostic, educational and advisory-consultative work with athletes will continue to be practiced regularly by other psychologists in other major competitions, since the departure and adaptation of the atmosphere in the Olympic Village or similar centres with a large number of well-known athletes and sportsmen star from around the world, many inexperienced athletes can cause great stress, pressure, distraction from personal competition goals, lack of focus on previously established training and competition routines, etc., which is a safe way (especially for athletes who are not accompanied by their trainers) to a bad competitive performance.

\section{National sports psychology through learning and applying psychological skills}

It has been repeatedly emphasized that psychological diagnosis or profiling of athletes is the basis of the activities of sport psychologists. It is the first step after which they decide what areas of their further intervention are, whether it is necessary for the athlete or all members of the team to train psychological skills, which model will be determined and which skills will be trained (concentrations and focusing, relaxation technique, visualization technique, setting goals, building confidence, team building, collective effectiveness, etc.), whether educational sessions for trainers and / or parents will be organized, work on the development of intrinsic motivation, etc. Sport psychologists and mental trainers in our country, as well as those in the world, work most at training psychological skills in athletes with that contribute to success in a given sport, and are equally usable and useful for life outside sports. Depending on the acquired knowledge in the sports psychology and sports sciences, the knowledge of certain psychotherapeutic and advisory techniques, the experience in working with athletes and theoretical orientations - sport psychologists apply different models in the provision of their services. Poczwardowski (Poczwardowski et al., 2004, according to Aoyagi and Poczwardowski, 2012) classifies them into five categories: (a) training / psychological training models (TPV), (b) counselling models, (c) medical models, (d) models of interdisciplinary sports science, and (e) supervised counselling models with an integrative approach. Within the model of psychological skills training, two broader groups are identified: in the first, the models are focused on practicing psychologists who provide advisory and consulting services to athletes (e.g. model of cognitive-behavioural consultations, model of counselling for young athletes, model of leading successful counselling), while in another there are models directly aimed at developing psychological skills in order to achieve sports excellence (Hanin's model of individual zones of optimal functioning, a pyramid model of sport excellence, a model of resonant performance by Nibarg et al., Orlick's wheel of excel- 
lence, Vernaciss model for superior performance, an integrative model of human performance by Gard- ner and Moore, mental skills model for athletes and coaches by Robin Vealey.

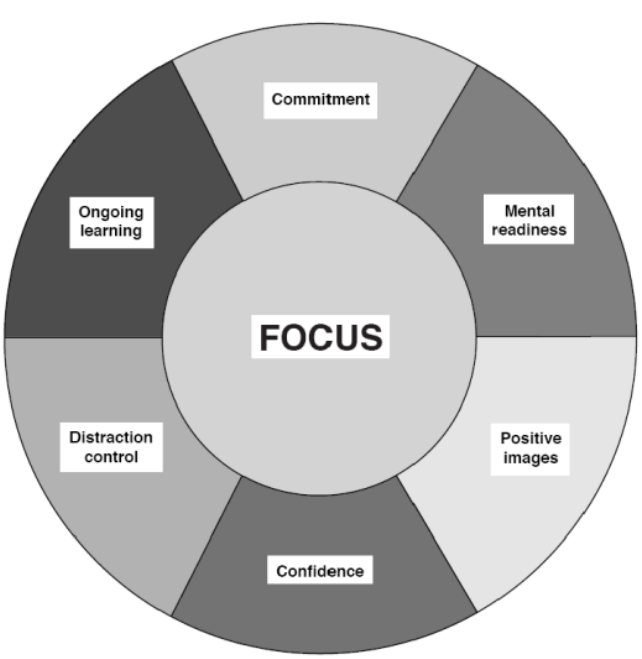

A

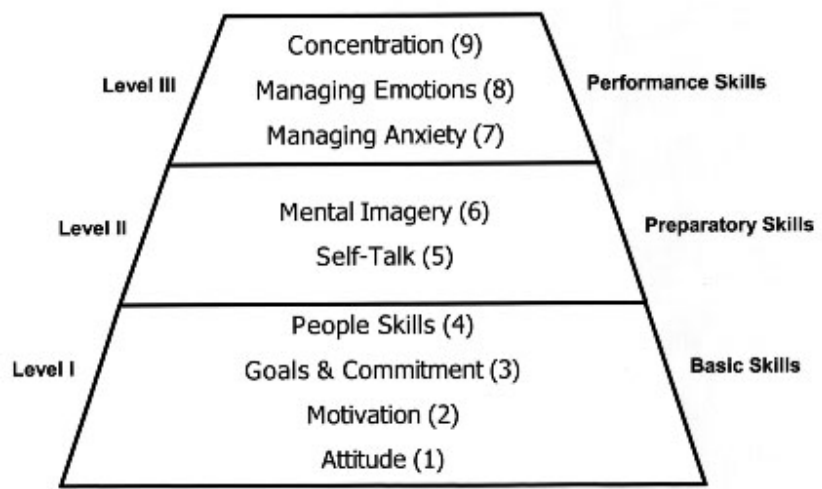

B

Figure 1. A: The Wheel of Excellence (taken from Orlick, T. 2008, p. 12); B: Nine mental skills (adapted, according to Lesyk, 2007)

Regardless of which model it is, all of them essentially contain training of similar psychological skills, they only have a different theoretical approach and are differently ranked by relevance or purpose. Let's take Orlick's model of the wheel of excellence (Orlick, 2008), which consists of seven critical elements that leads an athlete to excellence or mastery (Figure 1A). These are: focus (the most important element of excellence, the core or the centre of the circle), commitment (the key ingredient of excitement towards excellence), mental readiness (to do everything to make the athlete positive, focused, persistent, fully committed to his goals), positive visions and performances (using the power of positive visions, thoughts, mental imaginations, visualizations), self-confidence (belief in one's own potentials, ability to overcome obstacles and achieve goals, mental readiness, focus, choice, the significance of one's own mission and those for which he works or play), interference control (the ability to control external and internal distractors) and continuous learning (continuous learning, self-discovery and expand the frontiers of knowledge when an athlete takes achieved the best focus and execution). Unlike Orlick, whose model implies the primary focus of a psychologist on training athletes with skills that his wheel of excellence contains, the Vealey's Model of Mental Skills for athletes and trainers (Vealey,
2007, according to Aoyagi and Poczwardowski, 2012) combines various types of mental skills that affect performance and the well-being of individuals and teams. The model includes four categories of mental skills: basic skills, performance skills, personal development skills and team skills. The basic mental skills necessary for success are: the motive of achievement, self-awareness, productive thinking and self-confidence. The skills used during performance consist of perceptual-cognitive skills, focus of attention and energy management. The skills of personal development enable effective psychological functioning, and include the building of personal identity and interpersonal competence. Team skills are the qualities necessary for an effective team environment and success, and include team trust, cohesion, communication and leadership.

The model most similar to the one of Vealey's is Lesyk's (Lesyk, 2007) model of the pyramid of performance, based on his belief that nine specific mental skills that contribute to the sport success can be distinguished from all existing models (Figure 1B). They make a pyramid of performance in which basic skills necessary for achieving long-term goals, learning and maintaining daily training are on the basis or on the first level. They are needed daily for a longer period of time, often for months and years, and these 
are: positive attitude, motivation, goals and commitment and communication skills. On the second level there are skills that athletes use immediately before the performance and they serve as preparation for performance: the skill of using positive self-talk and the mental imagination or visualization skill. On the third level or the top of the pyramid, there are skills used during the actual performance, efficient managing anxiety, managing emotions and concentration skills. These skills are taught and improved through instruction and training, and psychologists start their training by assessing the knowledge of an athlete in the application of each of them (they usually use the Test of Performance Strategies - TOPS which measures to what extent athletes use skills for goal setting, automated performance, emotion control, imagination, activation or achievement of optimal excitement, self-talk, relaxation, negative thinking, attention control in specific situations in trainings and competitions. After that they develop a plan for training and improvement of specific skills necessary for that particular athlete. Of course, a periodical check of the athlete's ability in each skill is also necessary to evaluate the progress achieved.

\section{Sports psychology through Sports and Academic Cohabitation}

The need for psychological theory and practice is increasing both in national sports federations and clubs, as well as in professional and academic institutions in the field of sports. Every major national sports federation, like major clubs, is looking for one or more sport psychologists who will work for them. The engagement of sport psychologists by athlete's parents is constantly increasing since the end of the 1990s, so they must be prepared in particular for understanding the psychodynamics of family relationships and its impact on the child's sports career. Sport psychologists will increasingly be involved in working with young athletes, their trainers and parents, which contributes to minimizing negative sporting experiences, that parents understand their role properly and that they are the best way to play, that coaches achieve good communication with athletes and their parents, adopt a positive approach to coaching and create a climate-oriented mastery, learn good sporting behaviour, fair play and lifelong skills, recognize the educational potential of sports and accept roles in young people and their preparation to become healthy, satis- fied and productive members of the society. Also, it is necessary that new generation of sport psychologists, with the support of older and experienced colleagues, solve the burning problem of vocational training and licensing for clinical and advisory practice in the field of sports and physical exercise, to establish a register with the names of psychologists who have met the requirements of qualification for the role of sports educators and / or consultants of sports psychology, to bring ethical codes that will respect the specificities of their practice and to form a professional organization (association or section) that will care for creation and implementation of all technical and legislative measures and activities in order to improve the theory and practice of sport and exercise psychology and also contribute to reducing the number of unregistered and unqualified individuals whose actions and behaviour are in conflict with the high ethical standards of the psychological profession.

\section{The Sport Psychologist - a Step Forward towards New Subspecializations, roles and technologies}

Sport psychologists have to be prepared for new subspecializations within the sports psychology in time. As the sports psychology separated itself from motor learning and motor control in the middle of the last century, new subspecialties such as exercise psychology, development of lifestyle of youth through sport and performance excellence psychology (application of principles from sports psychology for increasing performance in other fields, such as art, music and business).

In the opinion of contemporary psychologists (Weinberg and Gould, 2011; Zaichkowsky, 2006) with traditional quantitative research, non-numerical, qualitative research methods will be increasingly used. The movement of positive psychology that has long since settled in the field of psychology in general, has been attracting more and more attention in the sports psychology, as it emphasizes the need for sport psychologists to focus more on the development of positive attributes of athletes, such as optimism, hope, wisdom, creativity, courage, humour and happiness as opposed to focusing on their disadvantages. Positive sports psychology opens up new opportunities for psychologists to transfer their knowledge acquired in sports to other areas, such as business, art, 
dance in which top performance is also required. We also believe that academic sport psychologists shall expand their roles (some of them have already done it), that is, that they will not only hold the role of lecturers of the formal curriculum of sports psychology, but will accept the role of counsellors and consultants in working with students on topics of interest (e.g. nostalgia for home and the inability to focus on learning, drug abuse, mood disorders , nutrition disorders, balance of academic and sports obligations), as well as engaging in formation and work in the counselling centre for athlete students at their faculties or in work with athletes outside the faculty (McCann, 2005).

The labour market for this profession will be limited (mostly geographically, since all the surrounding countries, some of which were regular users of the Serbian sports psychology services, now have their own experts whose number will increase in the future), so new methods of work with a wide range of

\section{REFERENCES}

6. About Division 47 (2018). Preuzeto sa http:// www.apadivisions.org/division-47/about/.

7. American Psychological Association Division 47 Exercise \& Sports psychology Policies \& Procedures (2011). Downloaded from: http://www. apadivisions.org/division-47/about/policies .pdf

8. Anshel, M. H. (2007). Applied Exercise Psychology: A practitioner's Guide to Improving Client Health and Fitness. New York: Springer Publishing Company, Inc.

9. Aoyagi, M. W. \& Poczwardowski, A. (2012). Models of Sports psychology Practice and Delivery. In S. Hanton and S. D Mellalieu (eds.), Professional Practice in Sports psychology: A Review (pp. 5-30). Abingdon, Oxon: Routledge.

10. APA Division-47 (2009). What Is Exercise Psychology and Sports psychology? Downloaded from: http://www.apadivisions.org/division-47/ about/resources/what-is.aspx

11. Association for Applied Sports psychology - APA (2018). About Applied Sport \& Exercise Psychology. Preuzeto sa http://www.appliedsportpsych. org/about/about-applied-sport-and-exercisepsychology/ potential clients should be found and applied. The fact that we have deeply embedded in the world of digital culture, sport psychologists must not be ignored, but adapt their practice to that reality. In other words, a large number of today's sport psychologists provide their services via the Internet, Skype, Viber and other modern means of telecommunications, which enable clients to establish contact with them no matter what part of the world they are located. However, psychologists must be aware of the fact that this modern technology, no matter how attractive and easily accessible it may be, brings certain limitations and unpredictable challenges with itself (Schinke, Hancock, Dubuc, \& Dorsh, 2006). Some clients have a strong need for counselling through personal contact, so the physical separation can be a significant barrier for them. And as Schinke et al. speculated (2006), the future technologies may soon overcome this communication separation in ways that are unthinkable today.

12. Bačanac, Lj. (2007). Psihološka dijagnostika u sportu - Aktualno stanje i savremene tendencije. [Psychological diagnostics in sport - Current state and contemporary tendencies. In Serbian] Međunarodna naučna konferencija "Analitika i dijagnostika fizičke aktivnosti”, Zbornik radova (pp. 302-317). Beograd: Univerzitet u Beogradu; Fakultet spota i fizičkog vaspitanja.

13. Bačanac, Lj. (2009). Psychodiagnosis of athletes: Past, Present and Future. In N. Dikić (Ed). Programme and Abstract Book (pp. 175-197). Belgrade: Fourth Congress of Sports Medicine and Sports Science of Serbia, 22-24 September 2009, Belgrade).

14. Bačanac, Lj. (2015). Elementi psihologije sporta. [Elements of psychology of sport. In Serbian] Autorizovana skripta. Beograd.

15. Cei, A. (2011). Ferruccio Antonelli: His work and legacy. International Journal of Sport and Exercise Psychology, 9(4), 356-361.

16. Cole, B. \& Cole, W. B. (2017). Myths About Sports psychology: 32 Misconceptions About The Mental Game Of Sports Explained. Downloaded from: http://www.mentalgame coach.com /articles/Sports psychologyMyths.html 
17. Cox, R. H. (2012). Sports psychology: Concepts and Applications, Seventh Edition. New York: McGraw-Hill, Connect Learn Succeed.

18. European Federation of Sports psychology (1995). FEPSAC Position Statement 1: Definition of Sports psychology. Downloaded from: http:// www. fepsac.com/activities/position_statements/

19. European Federation of Sports psychology (2011). FEPSAC Position Statement 9: Ethical principles of the European Sports psychology Federation. Downloaded from: http://www. fepsac. com/activities/ position_statements/

20. Keegan, R. (2016). Being a Sport Psychologist. London: Palgrave.

21. Kodeks etike psihologa Srbije (2000). [Code of Ethics of Psychologists of Serbia. In Serbian] Downloaded from: http://moodle.f.bg.ac.rs/file. php/126/ eticki_kodeks_dps.pdf

22. Kontos, A. P. and Feltz, D. L. (2008). The nature of Sports psychology. In T. S. Horn (Ed.), Advances in Sports psychology, Third Editions (pp.3-14). Champaign, IL: Human Kinetics.

23. Kremer, J. and Moran, A. P. (2008). Pure Sport: Practical Sports psychology. Hove, East Sussex: Routledge.

24. Lavallee, D., Kremer, J., Moran, A. and Williams, M. (2004). Sports psychology: Contemporary Themes. New York: Palgrave Macmillan.

25. Le Unes, A. \& Nation, J. (1999). Sports psychology - An Introduction. Chicago: Nelson-Hall Publishers.

26. Le Unes, A. (2011). Introducing Sports psychology: A Practical Guide. London: Icon Books, Ltd.

27. Lesyk, J. (2005). Sports psychology: Knowledge \& Skills Check List. Downloaded from: http://www. apadivisions.org/division-47/about/reasurces/ checklist.pdf

28. Lesyk, J. (2007). The Nine Mental Skills of Successful Athletes. Podium Sports Journal. Downloaded from: http://www. podiums- portsjournal.com/2007/02/17/the-nine-mentalskills-of-a-successful-athlete/

29. McCann, S. (2005). Roles: The Sport Psychologist. In S. Murphy (Ed.), The Sport Psych Handbook: A complete guide to today's best mental training techniques (pp. 279-291). Champaign, IL: Human Kinetics.

30. Moran, A. P. (2004). Sport and Exercise Psycology: A Critical Introduction. Hove, East Sussex: Routledge.

31. Orlick, T. (2008). In Pursuit of Excelence: How to win in sport and life through mental training. Champaign, IL: Human Kinetics.

32. Schinke, R.J., Hancock, D. \& Dubuc, N. G. (2006). Looking to the Future of Sports psychology: An Introduction. Athletic Insight - The Online Journal of Sports psychology, 8(3). Downloaded from: www.athleticinsight. com/Vol8Iss3/IntroFuture. htm

33. Singer, R., Hausenblas, H., Janelle, C. Eds. (2001). Handbook of Sports psychology. New York: John Wiley \& Sons, Inc.

34. Tod, D., Thatcher, J. and Rahman, R. (2010). Sports psychology. New York: Palgrave Macmillan.

35. Vesković, A., Petrović, N. (2017). Etičko obrazovanje u primenjenoj psihologiji sporta. [Ethical education applied in the psychology of sports. In Serbian]. Fizička kultura, 71(2), 127-136.

36. Weinberg, R. S. \& Gould, D. (2011). Foundations of Sport and Exercise Psychology, Fifth Edition. Champaign, IL: Human Kinetics.

37. Williams, J. M. \& Straub, W. F. (2010). Sports psychology: Past, Present, Future. In J. M. Wiliams (Ed.), Applied Sports psychology: Personal Growth to Peak Performance, Sixt Edition (pp. 1-17). New York: McGraw-Hill.

38. Zaichkowsky, L. D. (2006). Industry Challenges Facing Sports psychology. Athletic Insight - The Online Journal of Sports psychology. Downloaded from: http://www. athleticinsght. com/vol.8.Iss3/ 


\title{
ПСИХОЛОГИЈА СПОРТА У СРБИЈИ: КРИТИЧКИ ОСВРТ НА ПРЕБЕНИ ПУТ, АКТУЕЛНО СТАҢЕ И БУДУЋЕ ИЗАЗОВЕ
}

\author{
Љубица Бачанац \\ Факултет за спортски менаџмент, Универзитет Доња Горица, Подгорица, Црна Гора
}

\begin{abstract}
Сажетак
Дат је преглед кључних момената у развоју светске и домаће психологије спорта са истицањем специфичности и сличности које су тај развој пратиле. Дефинисањем психологије спорта кроз приказ националног развоја, као и преко предмета изучавања и активности спортских психолога, указано је на богатство садржаја и тема којима се она бави. Стасавање националне психологије спорта и вежбања праћено је кроз њено присуство и сазревање у стручним и академским институцијама у области спорта и физичког васпитања и преко значајних догађаја, публикација и имена појединаца који су обележили њене почетке, изузетно допринели њеном развоју, афирмацији и препознатљивости и трасирали пут за нове генерације стручњака који ће програмирати њено запажено присуство и будући развој у спортској и академској заједници Србије. Рад садржи и критички осврт на садашњи тренутак примењене и академске психологије спорта, са препорукама неопходних активности које ће отворити пут њеном бржем и још успешнијем будућем развоју.
\end{abstract}

КљУчне речи: ПСИХОЛОГИЈА СПОРТА / РАЗВОЈ / ПЕРСПЕКТИВЕ / БУДУЋИ ИЗАЗОВИ / СРБИЈА

\section{УВОД}

Данас, након више од пола века постојања психологије спорта у Србији (у саставу СФРЈ, СРЈ, СЦГ), и дуже од једне декаде њеног развоја у државно независној Републици Србији, важно је подсетити се на изазове и проблеме који су пратили њен развој, у мисији њеног одговора на научне и практичне изазове, на потребе и очекивања спортиста, тренера, родитеља спортиста, спортских стручњака, академске заједнице, као и других актера у националном систему спорта. Зашто је психологија спорта постала толико важна, прво је питање које захтева целовит и сврсисходан одговор. У трагању за одговором, познавање простора историје једне научне дисциплине, неопходно је за боље и дубље разумевање њене садашњости и компетентније планирање њеног будућег развоја.

Историја нас учи да развој психологије спорта у Србији није ишао праволинијски и узлазном путањом, већ да је имао своје успоне и падове.
Овакав, пендуларни развој (по систему клатна) је логичан, јер се одвијао у различитим друштвенополитичким контекстима кроз које је пролазило српско друштво, и који су неизбежно утицали на спорт одрећујући његову идеологију, философију, политику, приоритетне циљеве, али и место и улогу спортских наука у њеном академском развоју и развоју са циљемунапређења непосредне спортске праксе.

Намера је да осветљавајући главне одлике и постигнућа психологије спорта кроз два временска периода (44 године њеног развоја и функционисања у Србији у саставу Социјалистичке Федеративне Републике Југославије и Савезне Републике Југославије, тј. државне заједнице Србије и Црне Горе, те 12 година у државно независној Републици Србији ), укаже на главне проблеме са којима се сретала, како их је превазилазила, какво место и улогу је имала у унапређењу спортске праксе и науке. Након 
ова два периода, поставља се и питање да ли је психологија спорта оправдала очекивања стручне јавности и успела да се избори са бројним предрасудама и митовима који су је одувек пратили.

Ова анализа настоји да сагледа полазиште, тренутно стање и перспективе будуће мисије и развоја психологије спорта. Анализом су обухваћене и активности спортских психолога практичара и оних више академски оријентисаних. Од исте се очекује да укаже које су биле слабости, а које добре стране досадашњег развоја ове интер и мултидисциплинарне научне дисциплине, сходно чему, анализа треба да истакне, области психологије спорта које су оправдано или неоправдано остале занемарене, те да им се у будућности стратешки посвети много више пажње како би се стигло до циља, а то је заокружење целовитог бића психологије спорта.

Исходи анализе треба да садашње и будуће спортске психологе подстакну на развој, да њихов свакодневни рад испуне радозналошћу која ће довести до вишег нивоа професионалне компетентности и самопоуздања, афирмисати стручне и етичке стандарде у њиховом раду са изазовима будућих стремљења. Такође, намера je да се укаже на доминантне улоге и области стручне и научноистраживачке праксе спортских психолога у прошлости и данас, те да истакну могуће трендове њеног даљег развоја.

\section{Психологија спорта као научна дисциплина и професија}

Данас је спортска литература препуна цитата, изјава врхунских спортиста и тренера који су јединствени у ставу да је спорт од 50-90\% ментална активност, да се игра телом, а побеђује умом, као и да за врхунска спортска постигнућа није довољна само квалитетна физичка, техничка и тактичка припрема. То најбоље потврђују речи познатог боксера М. Алија и атлетичара Џ. Овенса: “Шампиони се не праве у теретани. Шампиони се праве од нечега што је дубоко у њима - жеље, сна и визије. Они морају имати вештину и вољу. Али воља мора бити јача од вештине»; “Сви имамо снове. Али, да би их остварили потребно је много одлучности, посвећености, самодисциплине и напора". Овакве и сличне изјаве директно упућују на значај психолошких фактора у спорту, а психологија спорта је посвећана управо тим факторима. Зато не чуди што све већи број спортиста и спортских тимова (клупских и националних селекција), како у свету тако и код нас, имају своје спортске психологе који им помажу да побољшају извођење, постигну највише онда када је најтеже - против најјачих ривала и на највећим такмичењима. Са овом тврдњом постављена је прва недоумица и дат је одговор на питање шта је психологија спорта и вежбања и чиме се психолози спорта и вежбања баве.

Тешко је дати једну свеобухватну дефиницију психологије спорта, не само због њене интер и мултидисциплинарне природе (повезује различите психолошке субдисциплине са спортским и вежбовним наукама, другим друштвенохуманистичким наукама и медицином), већ и због чињенице да она за различите људе значи различите ствари (Бачанац, 2010). Најчешће се дефинише преко предмета изучавања или активности спортских психолога, односно као проучавање психолошких или менталних фактора који утичу и/или су под утицајем бављења спортом или физичким вежбањем. Европско удружење запсихологију спорта усвојим полазним ставовима истиче да се она бави психолошким аспектима спорта, физичког вежбања/рекреације и физичког васпитања (FEPSAC, 2011), а дефинише је као изучавање психолошких основа, процеса и последица спорта (FEPSAC, 1995). Одељење 47 Америчке психолошке асоцијације, психологију спорта и вежбања дефинише као научно истраживање психолошких фактора који су повезани са учешћем и извођењем у спорту, вежбању и другим врстама физичке активности (APA, Division - 47, 2009). Наведене и многе друге дефиниције - као и Коксова која каже да је психологија спорта наука која психолошке принципе примењује у области спорта и вежбања (Cox, 2012, стр. 5) - акценат стављају на оно шта спортски психолози истражују, тј. оно чиме се највише бави академска психологија спорта, а не на то шта психолози раде у непосредној пракси.

Дефиниција Америчког удружења за примењену психологију спорта (AASP) наглашава управо те проблеме: примењена психологија спорта и вежбања обухвата проширење теорија и истраживања на едукацију спортских тренера, спортиста, родитеља, вежбача и фитнес стручњака 
о психолошким аспектима њиховог спорта или активности. Примарни циљ стручњака примењене психологије спорта и вежбања је да олакшају/подстакну оптималну укљученост, извођење и уживање у спорту и вежбању (AASP, 2018).

Можда је ову дискусију о предмету психологије спорта и вежбања најбоље закључити ставом већине савремених спортских психолога који наглашавају да се она односи на две широке области: (1) на изучавање утицаја психолошких и емоционалних фактора на спорт и вежбање, и (2) изучавање утицаја бављења спортом и вежбањем на психолошке и емоционалне факторе (Cox, 2012). Вајнберг и Гулд (Weinberg i Gould, 2011) истичу да психологија спорта и вежбања представља научно истраживање људи и њиховог понашања у спортским и вежбовним активностима и практичну примену тих знања. Психолози спорта и вежбања имају два задатка: (a) да разумеју како психолошки фактори утичу на извођење у спорту и вежбању и (б) да разумеју како бављење спортом и вежбањем утиче на развој, здравље, благостање и добробит особа.

\section{Психологија спорта у свету}

Скоро да нема ни једног уџбеника из психологије спорта који не наводи имена значајних психолога који су својим радом и достигнућима трајно обележили настанак ове примењене психолошке науке, њен карактеристични развој у одређеним временским периодима, допринели настанку бројних струковних удружења и организација, специјализираних часописа и трасирали пут за будуће трендове њеног развоја (Cox, 2012; Keegan, 2016; Lavallee, Kremer i Moran, 2008; Le Unes i Nation, 1999; Moran, 2004; Singer, Hausenblas i Janelle, 2001; Tod, Thatcher i Rahman, 2010; Weinberg i Gould, 2011; Williams i Straub, 2010).

Мада се настанак психологије спорта везује за крај 19. и почетак 20. века када је Норман Триплет 1898. извео први социјално-психолошки експеримент и утврдио да бициклисти возе брже у присуству других него када возе сами, њен настанак као самосталне научне психолошке дисциплине дешава се 60-их и 70-их година 20. века. Триплетов експеримент је послужио као инспирација Зајонцу да 1965. постулира теорију социјалне фацилитације која најбоље објашњава како на спортско извођење утиче присуство публике, зашто постоји предност домаћег терена, зашто долази до „гушења под притиском“, када у спортским тимовима долази до појаве „социјалног забушавања“ и како кохезија тима утиче на такмичарско постигнуће.

Када говоре о историји психологије спорта, Вајнберг и Гулд (2011) је деле на шест карактеристичних периода, Сингер (2001) наводи пет, а Кокс (2012) и други аутори (нпр. Lavalee и сар, 2004; Keegan, 2016; Moran, 2004) то чине наводећи имена психолога који су својим доприносима у домену истраживања и/или праксе обележили поједина раздобља њеног бржег или споријег развоја.

Без намере упуштања у детаљније навођење свих битних особа и датума важних за развој психологије спорта и вежбања, следи кратак осврт на шест карактеристичних периода њене историје у САД, као и кључне датуме и личности које су обележиле историју психологије спорта (ПС) у Европи. Већ је речено да је Триплет обележио први период или „Ране године“ како га називају Вајнберг и Гулд (2011). Овај период започиње 1893, а завршава се 1920, а сем Триплета обележили су га Скрипче (Scripture) истраживањем брзине реакције и покрета и описом црта личности за које је веровао да се могу подстицати кроз бављење спортом, и Патрик (Patrick) расправама о психологији игре.

Други период или „Грифитова ера“ (19211938) обележио је психолог Колеман Грифит, кога називају оцем америчке психологије спорта. Он је највећи део своје научне каријере посветио психологији спорта, публиковао 25 истраживачких радова из ове области и написао две класичне књиге: Психологија тренирања (1926) и Психологија спорта (1928). Осим тога, он је био иницијатор једне од првих тренерских школа у Америци, а 1925. је на Универзитету Илиноис основао лабораторију за истраживања у спорту.

Трећи период (1939-1965) Вајнберг и Гулд (2011) називају „Припрема за будућност“, а обележио га је рад Хенрија Френклина (Henry Franklin) са Беркли универзитета који се први бавио психолошким аспектима стицања моторних вештина у спорту, развио програм за психологију физичке активности намењен 
студентима физичког васпитања и едуковао велики број истакнутих стручњака у домену кинезиологије. Тај период су обележили Дороти Јеитс (Dotorhiy Yates) радом са боксерима на колеџима и истраживањем ефеката тренинга релаксације, Варен Џонсон (Warren Johnson) који је процењивао предтакмичарске емоције код спортиста и Џон Лотер (John Lawther) који је написао књигу Психологија тренирања. Година 1965. и град Рим су најважнији датум и место у историји психологије спорта, јер је тада основана прва струковна организација спортских психолога - Међународно удружење за психологију спорта (ISSP) и одржан први међународни конгрес спортских психолога.

Четврти период (1966-1977) јекарактеристичан по заснивању психологије спорта као академске дисциплине различите од моторног учења, са широким спектром истраживачких тема и практичним радом са спортистима и тимовима који је први започео Брус Огилви (Bruce Ogilvie), па га називају и оцем примењене психологије спорта у Северној Америци. Он је са Т. Татком (Thomas Tutko) 1966. написао познату књигу Проблем спортиста и како са њима радити. У том периоду, тачније, 1967. оснива се прво Северноамеричко удружење за психологију спорта и физичку активност (NASPSPA), а 1970. почиње да излази први часопис International Journal of Sport Psychology. Незаобилазна имена овог периода су Брајан Крати (B. Crraty) и његова књига Психологија физичке активности, као и Роберт Сингер са књигом Моторно учење и људско извођење.

Пети период (1978-2000) под називом „Мултидисциплинарна наука и пракса у психологији спорта и вежбања" карактерише се огромним растом истраживања, све већим бројем психолога практичара, оснивањем нових струковних организација, одржавањем конференција и конгреса, појавом специјализованих часописа и књига. Тешко је издвојити појединце и догађаје који су га обележили, али свакако треба поменути Дороти Харис (Dorothy Harris) коју због њених доприноса с правом називају „мајком психологије спорта“. За овај период се везују прва издања часописа: Журнал за психологију спорта (1979, сада Журнал за психологију спорта и вежбања), Спортски психолог (1986), Журнал за примењену психологију спорта (1989), као и оснивање две важне организације: Савез за унапређење примењене психологије спорта (AAASP, 1986) и Одељење 47 Америчке психолошке асоцијације (APA Division-47; 1986) која покрива поље психологије вежбања и спорта (About Div. 47).

Шести период тече од 2001. па до данас, а Вајнеберг и Гулд га називају периодом савремене психологије спорта и вежбања који стално напредује, проширује и усавршава методе научно истраживачког и практичног рада. Међу многим психолозима спорта и вежбања који заслужују да им се помене име, је Раинер Мартенс, бивши професор психологије спорта на Универзитету Илиноис, оснивач највеће издавачке куће у области спорта Human Kinetics Publishers и аутора до сада непревазиђеног приручника за Амерички програм едукације у спорту (АCEP) Успешно тренирање (1990...2012).

Паралелно са развојем психологије спорта у Америци, тече и њен развој у Европи. Везује се за име Пјера Кубертена, председника Међународног олимпијског комитета (МОК), од 1896. до 1925. Године, који је први увео термин психологија спорта (Cox, 2012). Он је организовао два олимпијска конгреса (1897. у Француској и 1913. у Швајцарској) на којима су биле и теме из психологије спорта, а на конгресу у Швајцарској (Лозана) први пут је формално психологија спорта означена као нова дисциплина у оквиру спортских наука, па се та година, по мишљењу Кубертена, оца европске психологије спорта, сматра рођенданом ове науке у Европи. Европски спортски психолози, посебно совјетски, немачки и чешки, почињу да се озбиљније баве проблемима психологије спорта истовремено када и Колеман Грифит у Америци (Бачанац, 2015). Прву лабораторију за психологију спорта основао je Carl Diem 1920. године у Немачкој спортској школи у Берлину. Само пет година касније (1925) Пуни отвара спортско психолошку лабораторију у Институту за физичку културу у Лењинграду, а Одељење за психологију спорта отворено је 1930. године. Његов колега Рудик оснива прву спортско-психолошку лабораторију у Совјетском савезу у Институту за физичку културу у Москви 1925. године. Важно је напоменути да је Пуни касних 60-их и раних 70-их 20. века, развио и публиковао свој модел „Психолошке припреме за такмичење“, у време када су амерички спортски психолози били више фокусирани на спортске 
науке него на примењену психологију спорта (Cox, 2012).

Човек који је највећи део свог живота посветио психологији спорта био је Италијан Феручо Антонели (Ferruccio Antonelli). Он је 1965. у Риму организовао Први међународни конгрес спортских психолога, на коме је основано Међународно удружење спортске психологије (ИССП) које је повезало спортске психологе широм света (Cеi, 2011). Пет година касније, 1970, Антонели покреће први научни часопис у целости посвећен психологији спорта International Journal of Sport Psychology (сада International Journal of Sport and Exercise Psychology). Осим поменутих совјетских психолога Пунија, Рудика и Родионова, велики допринос развоју психологије спорта и њеној примени у пракси дали су бројни британски, чешки, немачки, бугарски, швајцарски спортски психолози, као што су Ванек, Хошек, Свобода, Мачак, Гизе, П. Кунат, Е. Герон, Ф. Генов, Е. Апич, Шилинг и други. Велики подстицај за даљи развој и унапређење европске психологије спорта добија оснивањем Европске федерације за психологију спорта (ФЕПСАЦ) 1968. године, успостављањем праксе редовних европских конгреса спортских психолога (од 1969.) и покретањем часописа Psychology of Sport and Exercise (1970), који спада у категорију најутицајнијих и најпрестижнијих научних часописа у широком подручју психологије спорта и вежбања.

\section{Психологија спорта у Србији - јуче и данас}

Историју психологије спорта у Србији пратићемо кроз њен развој у стручним, наставним и научним институцијама у области спорта и преко значајних догађаја и публикација домаћих аутора посвећеним њеним темама и садржајима, а намењеним стручњацима у спорту и студентима спортских наука. Бачанац (2015) сматра да се историја психологије спорта у бившој СФРЈ (Социјалистичкој Федеративној Републици Југославији), а самим тим и данашњој Републици Србији, у то време једној од њених 6 конститутивних целина - везује за Југословенски завод за физичку културу и медицину спорта (ЈЗФКМС). Основан је 1956. године као прва стручна и научна институција са циљем унапређења свих сегмената физичке културе (спорта, рекреације, физичког васпитања) на целокупној територији тадашње Југославије. Шест година касније, тј. 1962. ЈЗФКМС постаје прва установа у области спорта, како у бившој СФРЈ, тако и у Србији, у којој је за потребе спортске теорије и праксе, основана Лабораторија за психологију спорта.

Са дипломом психолога и искуством стеченим кроз сопствену атлетску каријеру, Мирјана Драгићевић започиње општа психолошка знања примењивати на спорт, бавити се психолошком дијагностиком, саветовањем и психолошком припремом спортиста. На њено место 1974. долази психолог Љубиша Лазаревић (са личним спортским искуством у фудбалу) који наставља започету праксу, ради на даљем унапређењу методологије психолошке процене спортиста и започиње прва истраживања мотивације за бављење спортом и утврђивања специфичности профила личности, мотивације постигнућа и когнитивних способности спортиста различитог нивоа успешности. Он је први спортски психолог који је био званични члан и стручни консултант наших спортиста на Олимпијским играма у Монтреалу (1976), Москви (1980) и Лос Анђелесу (1984). Због огромног доприноса развоју и унапрећењу примењене и академске психологије спорта (написаоје значајнеуџбеникеи приручнике за студенте спортских наука и психологе практичаре - видети табеле 1 и 2), он се с правом може назвати оцем српске психологије спорта. У ЈЗФКМС 1976. године долази Љубица Бачанац, која се пуних 36 година бавила примењеном психологијом спорта, истраживачким радом и едукацијом тренера, спортиста, родитеља спортиста и других учесника у спорту. Ипак, највише пажње посветила је унапређењу дечијег и омладинског спорта, настојећи да афирмише његове васпитне и социјализацијске вредности, да осветли његову значајну улогу у свестраном биопсихо- социјалном развоју и здрављу, да смањи све видове насиља и непримереног понашања која га прате и тако деци и младим спортистима омогући да кроз спорт лепше и здравије расту. У улогама спортских психолога, као стално запослени у овој установи, опробало се, и краће или дуже задржало, још неколико психолога (Весковић А., Николић М., Илић J.). Заједнички рад Лазаревића и Бачанац седамдесетих и осамдесетих година прошлог века резултирао је успостављањем тесне 
сарадње између тренера и спортиста с једне и спортских психолога са друге стране. Спортски психолози су постали стални чланови стручних тимова свих успешних спортских савеза у тадашњој Југославији и садашњој Србији, а њихове услуге доступне су свим заинтересованим корисницима.

Паралелно са развојем психологије спорта у ЈЗФКМС, сада Завод за спорт и медицину спорта Србије, психологија спорта се борила и изборила за своје место у наставном плану и програму Факултету спорта и физичког васпитања у Београду. Иако је ова високо образовна установа основана далеке 1946. године као Државни институт за физичку културу, у њој се психологија спорта као самостални и обавезни наставни предмет, а не у саставу опште психологије и моторне контроле, почела изучавати тек од 2000. па све до 2012. године, када, нажалост, добија статус изборног наставног предмета. Осим важних тема из психологије спорта, студенти спорта и физичког васпитања специфична психолошка знања стичу и кроз наставу неколико других предмета, као што су општа психологија, развојна психологија, моторна контрола, дечији спорт, жена и спорт. На овај начин они добијају солидну основу да своје професионалне активности у улози наставника физичког васпитања, спортских тренера, вежбовних лидера и стручњака у свим другим видовима физичке активности (фитнеса, рекреације) обављају далеко успешније, са више компетентности и самопоуздања.

Табела 1 Хронологија развоја психологије спорта у Србији (преузето и допуњено према Бачанац, 2009, 2015)

\begin{tabular}{|c|c|c|}
\hline Година & $\begin{array}{l}\text { Догађаји од значаја за развој националне } \\
\text { психологије спорта }\end{array}$ & Психологија спорта кроз високо образовање \\
\hline 1953. & $\begin{array}{l}\text { Оснива се Спортски институт Војводине; } \\
\text { више пута мења назив и осниваче (сада: } \\
\text { Покрајински завод за спорт и медицину } \\
\text { спорта). }\end{array}$ & \multirow{2}{*}{$\begin{array}{l}\text { У Београду се оснива } \\
\text { Државни институт за } \\
\text { физичку културу, ДИФ } \\
\text { (сада: Факултет спорта и } \\
\text { физичког васпитања) }\end{array}$} \\
\hline 1956. & $\begin{array}{l}\text { Оснива се Југословенски завод за физичку } \\
\text { културу и медицину спорта (сада: Завод за } \\
\text { спорт и медицину спорта Републике Србије) }\end{array}$ & \\
\hline 1962. & $\begin{array}{l}\text { ЈЗФК запошљава првог психолога са } \\
\text { задатком да се бави проблемима психологије } \\
\text { спорта и изађе у сусрет нараслим } \\
\text { проблемима спортске праксе. }\end{array}$ & $\begin{array}{l}\text { Од оснивања ФСФВ па све до } 2000, \text { Психологија спорта } \\
\text { се изучавала у оквиру предмета „Психологија“. }\end{array}$ \\
\hline 1975. & $\begin{array}{l}\text { У ЈЗФК-у раде два спортска психолога и } \\
\text { тај број остаје исти до 2010. године. Сада у } \\
\text { Републичком заводу за спорт раде стално } \\
\text { запослена три сп. психолога и по } 1 \text { или више } \\
\text { волонтера, дипломираних психолога. }\end{array}$ & $\begin{array}{l}\text { Психологија спорта се } \\
\text { изучава као посебан и } \\
\text { обавезан предмет на одсеку } \\
\text { за спорт . }\end{array}$ \\
\hline 1975. & $\begin{array}{l}\text { - Параносић, В., Лазаревић, Љ.: } \\
\text { Психодинамика спортске групе. Београд: } \\
\text { Савез за физичку културу Југославије. }\end{array}$ & $\begin{array}{l}\text { Првообјављена књига са тематиком из психологије } \\
\text { спорта }\end{array}$ \\
\hline
\end{tabular}




\begin{tabular}{|c|c|c|}
\hline 1981. & $\begin{array}{l}\text { - Хавелка, Н., Лазаревић, Љ.: Спорт и } \\
\text { личност. Београд: Спортска књига. }\end{array}$ & \multirow{13}{*}{$\begin{array}{l}\text { Психолошко образовање будућих стручњака у } \\
\text { спорту и наставника физичког васпитања, осим кроз } \\
\text { програм предмета Психологија спорта одвија се и кроз } \\
\text { програме следећих наставних предмета: }\end{array}$} \\
\hline 1982 & $\begin{array}{l}\text { - Младеновић, У.: Основе психологије } \\
\text { спорта. Н. Сад: Завод за физичку културу } \\
\text { Војводине. }\end{array}$ & \\
\hline 1987. & $\begin{array}{l}\text { - Параносић, В.: Психологија спорта. } \\
\text { Београд: Нип Партизан. }\end{array}$ & \\
\hline 1994. & $\begin{array}{l}\text { - Лазаревић, Љ.: Психолошке основе } \\
\text { физичке културе. Београд: Виша школа за } \\
\text { спортске тренере. Допуњено издање } 2001 .\end{array}$ & \\
\hline 1996. & $\begin{array}{l}\text { - Лазаревић: Психолошка припрема } \\
\text { спортиста. Београд: Виша школа за спортске } \\
\text { тренере. Допуњено издање } 2003 .\end{array}$ & \\
\hline 2003. & $\begin{array}{l}\text { - Дунђеровић, Р.: Психологија спорта. Н. Сад: } \\
\text { Факултет физичке култ. }\end{array}$ & \\
\hline 2004. & $\begin{array}{l}\text { - Пајевић, Д.: Психологија спорта и } \\
\text { рекреације. Лакташи: Графомарк }\end{array}$ & \\
\hline 2004. & $\begin{array}{l}\text { - Бачанац, Љ.: Психолошки аспекти } \\
\text { оријентиринга. Ниш, „Круг“: Савез за } \\
\text { оријентациони спорт Београда. }\end{array}$ & \\
\hline 2005. & $\begin{array}{l}\text { - Бачанац, Љ.: „Моторне вештине - } \\
\text { психолошки приступ“; скрипта за студенте } \\
\text { спорта (више пута допуњавана, последњи } \\
\text { пут 2017.) }\end{array}$ & \\
\hline 2005. & $\begin{array}{l}\text { - Бачанац, Љ.: Елементи психологије } \\
\text { спорта“- скрипта за интерну употребу; } \\
\text { (последњи пут допуњена 2015.). }\end{array}$ & \\
\hline 2007. & $\begin{array}{l}\text { - Бачанац, Љ., Радовановић, И.: Васпитање } \\
\text { кроз спорт. Београд: Учитељски факултет. }\end{array}$ & \\
\hline 2008. & $\begin{array}{l}\text { - Бачанац, Љ., Шкоф, Б. (2007). Взгојне } \\
\text { налоге ин равнања учитељев/тренерјев при } \\
\text { делу з младими в шпорту. У Б. Шкоф (Ур.), } \\
\text { Шпорт по мери отрок ин младостников } \\
\text { (стр. 88-112), Љубљана: Факултета за шпорт. }\end{array}$ & \\
\hline 2009. & $\begin{array}{l}\text { - Покрајац, Б.: Психологија спорта. } \\
\text { Београд: Висока школа струковних студија } \\
\text { "Академија фудбала“ }\end{array}$ & \\
\hline 2010. & $\begin{array}{l}\text { Покрајински завод за спорт први пут } \\
\text { запошљава спортског психолога }\end{array}$ & $\begin{array}{l}\text { Психологија спорта } \\
\text { постаје изборни наставни } \\
\text { предмет. }\end{array}$ \\
\hline
\end{tabular}




\begin{tabular}{|c|c|c|}
\hline 2011. & $\begin{array}{l}\text { - Бачанац, Љ., Петровић, Н., Манојлович, } \\
\text { Н.: Психолошке основе тренирања младих } \\
\text { спортиста. Београд: Републички завод за } \\
\text { спорт }\end{array}$ & \multirow{7}{*}{$\begin{array}{l}\text { У оквиру великог броја виших и високих школа које } \\
\text { се баве образовањем кадрова у области спорта и физ. } \\
\text { васпитања, а лоциране у Београду, Нишу, Н. Саду, } \\
\text { Лепосавићу, Н. Пазару, спортски психолози се баве } \\
\text { академском психологијом спорта, тј. едукацијом } \\
\text { студената будућих стручњака у области спорта, } \\
\text { вежбања и физичког васпитања, а само ретки } \\
\text { појединци и практичним радом са спортистима. }\end{array}$} \\
\hline 2012. & $\begin{array}{l}\text { - Хавелка, Н., Лазаревић, Љ.: Психологија } \\
\text { менаџмента у спорту. Београд: Висока } \\
\text { спортска и здравствена школа. }\end{array}$ & \\
\hline 2015. & $\begin{array}{l}\text { - У Београду се формира прво удружење СП } \\
\text { „Секција за психологију спорта“у оквиру } \\
\text { Друштва психолога Србије. Бројала је } 22 \\
\text { СП. Нажалост, била је кратко активна, и већ } \\
\text { после годину дана њене активности замиру. }\end{array}$ & \\
\hline 2016. & $\begin{array}{l}\text { - Бачанац, Љ.: Агресивност и насиље у } \\
\text { спорту, Београд: Завод за уџбенике. }\end{array}$ & \\
\hline 2017. & $\begin{array}{l}\text { - Бачанац, Љ., Петровић, Н., Манојловић, Н.: } \\
\text { Спорт и насиље: Емпиријска анализа насиља } \\
\text { у спорту Србије. Београд: Спортски савез } \\
\text { Србије. }\end{array}$ & \\
\hline 2017. & $\begin{array}{l}\text { - Бачанац, Љ., Шкоф, Б. (2016). Педагошки } \\
\text { ин психо-социални видики шпорта младих. } \\
\text { У Б. Шкоф и Н. Братина (Ур.), Шпорт по } \\
\text { мери отрок ин младостников. 2. дополњена } \\
\text { издаја (стр. 128-271). Љубљана: Факултета за } \\
\text { шпорт. }\end{array}$ & \\
\hline 2018. & $\begin{array}{l}\text { - Весковић, А.: Психологија спорта: } \\
\text { Одабране теме, Београд: Факултет спорта и } \\
\text { физичког васпитања. } \\
\text { - Весковић, А.: Психологија вежбања: } \\
\text { Одабране теме, Београд: Факултет спорта и } \\
\text { физичког васпитања. }\end{array}$ & \\
\hline
\end{tabular}

О кључним моментима у развоју психологије спорта у Србији може се говорити и навођењем важних датума у вези са њеним настанком, личностима који су обележиле поједине периоде, спортским догађајима на којима су спортски психолози били укључени у функцији пружања стручне помоћи спортистима и тренерима и значајним публикацијама из домена психологије спорта и вежбања. Такви подаци су сажети у табели 1 , док су у табели 2 садржане чињенице за анализу упоредног развоја психологије спорта у Србији са њеним развојем у другим земљама (САД и Европа). Ако се пажљиво анализирају подаци из табеле 2, види се да се психологија спорта у Србији појављује као самостална научна и примењена психолошка дисциплина истовремено када и у свету, чак и нешто раније, ако се за критеријум њеног стварног препознавања и признања у породици спортских наука, узме година запослења првог спортског психолога са пуним радним временом, а то је било 1962. г., много пре него што је нпр. у САД (1985. г., према подацима Вајнберга и Гулда, 2011). Слично је и са ангажовањем спортских психолога на великим светским такмичењима. Спортски психолог Љубиша Лазаревић је званично био у саставу Југословенског олимпијског тима на Медитеранским играма у Алжиру 1975. године, а затим и на Олимпијским играма у Монтреалу 1976. и Москви, 1980, док су спортски психолози 
Бачанац љ., Психологија спорта у Србији..., ФИЗИЧКА КУЛТУРА 2019; 73 (1): 40-60

у САД званично уврштени у састав олимпијских тимова од 1984. (Bull, 2009), а према другим изворима то се десило 1987. године (McKann, 2005), односно 1988. (Kremer i Moran, 2008).

Табела 2 Корпоративни приказ кључних момената у развоју психологије спорта у Србији и свету

\begin{tabular}{|c|c|c|}
\hline Година & Србија & Свет \\
\hline 1956. & $\begin{array}{l}\text { У Београду се оснива ЈЗФКМС (данас: Завод } \\
\text { за спорт и медицину спорта Републике } \\
\text { Србије) }\end{array}$ & \multirow{2}{*}{$\begin{array}{l}\text { - 1965. : У Риму се оснива ISSP- International Society } \\
\text { of Sport Psychology } \\
\text { - Одржава се први светски конгрес психолога } \\
\text { спорта }\end{array}$} \\
\hline $1962: 1$ СП & $\begin{array}{l}\text { ЈЗФКМС запошљава првог психолога да се } \\
\text { бави проблемима психологије спорта }\end{array}$ & \\
\hline $1975: 2$ СП & \multicolumn{2}{|c|}{$\begin{array}{l}\text { ЈЗФКМС запошљава још } 1 \text { СП. Пуних } 35 \text { год. } 2 \text { СП покушавају да задовоље стално растуће потребе } \\
\text { југословенског, а затим српског спорта. }\end{array}$} \\
\hline 1975. & $\begin{array}{l}\text { Југословенски олимпијски комитет први } \\
\text { пут званично укључује сп из ЈЗФКМС у } \\
\text { стручни тим за пружање медицинске и } \\
\text { психолошке подршке спортистима на } \\
\text { Медитеранским играма у Алжиру. }\end{array}$ & \multirow{2}{*}{$\begin{array}{l}\text { - } 1968 . \text { на ОИ у Мексику, СП М. Ванек је у саставу } \\
\text { чехословачког ОТ; } \\
\text { - Од 1960. и ОИ у Мелбурну, СП налазе се у саставу } \\
\text { ОТ земаља Источне Европе; } \\
\text { - Од 1970. спортисти Источне Немачке и Совјетског } \\
\text { Савеза редовно користе услуге СП; } \\
\text { - } 1976 . \text { амерички олимпијски тим први пут добија } \\
\text { СП за ОИ у Монтреалу. }\end{array}$} \\
\hline 1976. & $\begin{array}{l}\text { У саставу Олимпијског тима на ОИ у } \\
\text { Монтреалу налази се СП из ЈЗФКМС. }\end{array}$ & \\
\hline 1979. & $\begin{array}{l}\text { У стручном тиму за Медитеранске игре у } \\
\text { Сплиту, налазе се } 2 \text { СП из ЈЗФКМС која су } \\
\text { на располагању спортистима током целог } \\
\text { такмичења. }\end{array}$ & $\begin{array}{l}\text { - 1980. Олимпијски комитет САД формира } \\
\text { Саветодавни одбор за психологију спорта. } \\
\text { - } 1985 . \text { ОКСАД први пут запошљава СП са пуним } \\
\text { радним временом } \\
\text { - } 1988 . \text { олимпијски тим САД званично прате } \\
\quad \text { признати спортски психолози } \\
\end{array}$ \\
\hline 1980. & $\begin{array}{l}\text { РЈ на ОИ у Москви, налази } \\
\text { МС. }\end{array}$ & \multirow{2}{*}{$\begin{array}{l}\text { - } \\
\text { Од 1984. услуге СП редовно користе амерички } \\
\text { спортисти учесници ОИ летњих и зимских ОИ; } \\
\text { - } \quad \text { У ОК САД запослена су } 4 \text { СП са пуним радним } \\
\text { временом: } 3 \text { у Олимпијском тренажном центру у } \\
\text { Колорадо Спрингсу, а } 1 \text { у Сан Дијегу. }\end{array}$} \\
\hline 1984. & $\begin{array}{l}\text { У саставу ОТ СФРЈ на ОИ у Лос Анђелесу, } \\
\text { налази се } 1 \text { СП из ЈЗФКМС. }\end{array}$ & \\
\hline 2009. & \multicolumn{2}{|c|}{ У саставу тима ОКС на ЕҮОФ у Тампереу (Финска) налази се 1 СП из РЗС. } \\
\hline 2010: 3 SP & \multicolumn{2}{|c|}{ Збор нараслих потреба спортске праксе РЗС запошљава још једног СП, тако да их има укупно 3.} \\
\hline 2011. & \multicolumn{2}{|c|}{ У саставу тима ОКС на ЕҮОФ у Трабзону (Турска) налази се 1 СП из РЗС. } \\
\hline $\begin{array}{l}\text { 2011: } \\
4 \text { SP }\end{array}$ & \multicolumn{2}{|c|}{$\begin{array}{l}\text { Завод за спорт и медицину спорта Р. Србије запошљава још једног СП, јер Лабораторија за } \\
\text { психологију спорта из дана у дан повећава обим своје истраживачке и стручне активности. Од } 2011 . \\
\text { до 2013. године у РЗС раде } 4 \text { стално запослена спортска психолога. }\end{array}$} \\
\hline 2012. & \multicolumn{2}{|c|}{ У Саставу тима ОКС на ОИ у Лондону налази се 1 СП из ЗСМСРС. } \\
\hline 2013: 3 SP & \multicolumn{2}{|c|}{ У ЗСМСРС раде 3 стално запослена СП и један по уговору. } \\
\hline 2014: 1 SP & \multicolumn{2}{|c|}{$\begin{array}{l}\text { 3СМСРС напуштају } 2 \text { СП и крајем године остаје само } 1 \text { стално запослен и један ангажован по } \\
\text { уговору. Такво стање остаје све до почетка 2018. године, када се број стално запослених повећава } \\
\text { на } 2 \text { СП. }\end{array}$} \\
\hline 2018: 2 SP & \multicolumn{2}{|c|}{$\begin{array}{l}\text { Почетком године Завод запошљава још } 1 \text { СП, тако да у овој републичкој, стручној и научној } \\
\text { установи тренутно раде } 2 \text { стално запослена СП. }\end{array}$} \\
\hline Напомена & \multicolumn{2}{|c|}{ У досадашњем периоду рада Завода тестирано је више од 19.000 спортиста! } \\
\hline
\end{tabular}

СКРАЋЕНИЦЕ: ЈЗФКМС - Југословенски завод за физичку културу и медицину спорта; СП- спортски психолог; ПС- психологија спорта; СФРЈ - Социјалистичка Федеративна Република Југославија; ОК- Олимпијски комитет; ОТ- олимпијски тим; САД - Сједињене Америчке Државе; РЗС- Републички завод за спорт; ЗСМСРС- Завод за спорт и медицину спорта Републике Србије - наследник РЗС. ОКС-Олимпијски комитет Србије. ЕYOF - Европски омладински олимпијски фестивал 
Ако се као критеријум за упоредну анализу узме време настанка првих значајних публикација из домена психологије спорта, онда се може закључити (табела 1) да Србија добрано касни „за светом“, јер је прва домаћа публикација Психодинамикаспортскегрупеобјављенатек 1975. године, док су Колеман Грифит своју Psychology of Coaching и Psychology of Athletics објавили далеке 1926. и 1928. године, а од тада па до данас у САД непрекидно се објављују нове књиге, приручници, монографије и уџбеници, који заједно са специјализованим часописима доприносе да теоријска и практична знања из психологије спорта допру до свих заинтересованих корисника. Ипак, почетком 1980-их, а нарочито од 2000-их долази до видног раста домаћих публикација што је последица све веће активности академских спортских психолога, али и значајних научно истраживачких пројеката психолога практичара вођених потребом да добијена сазнања учине доступним свим стручњацима спортских наука и праксе, а нарочито спортским психолозима.

Подаци презентовани у табели 2 говоре да се до краја 2012. године уочава тренд раста броја стално запослених спортских психолога у Заводу за спорт у Београду, а након тога се њихов број знатно смањује да би данас износио само два квалификована спортска психолога. Истовремено овај тренд смањења броја спортских психолога у спортским установама прати раст њихове присутности на слободном тржишту. Бројни појединци који себе називају спортским психолозима нуде своје услуге у оквиру личне приватне праксе, а да при томе нема никаквих података о њиховим квалификацијама за тај посао. Наравно ово је праћено одсуством постојања националног удружења за психологију спорта са свим атрибутима које таква удружења доносе и доприносе развоју професије.

Из табела 1 и 2 јасно сеуочава да је развој домаће психологије спорта паралелно текао у образовним институцијама (факултети спорта и физичког васпитања) и стручним институцијама, као што су институти или заводи за спорт (ЈЗФКМС, РЗС, Покрајински завод за спорт). Некада је он био видљивији и интензивнији у стручним спортским институцијама, а некада у академским. Пошто су спортски психолози традиционално академски или практично оријентисани (Kontos i Feltz, 2008), а неки у свом раду обједињују обе улоге, занимљива је чињеница да у бившој СФРЈ, а од 2006. у Србији као самосталној држави, психолози који се баве примењеном психологијом спорта након одређеног искуства стеченог у пракси прихватају улогу академских психолога и врло често обједињују и практикују обе улоге, тј. и примењену и академску. Обрнут пут, да се академски спортски психолози после одређеног времена ангажују у непосредној спортској пракси, колико је нама познато, код нас није забележен, мада у свету таква пракса постоји. Исто тако, и даље постоји приличан раскорак између теорије и праксе, односно између академски и практично оријентисаних спортских психолога, али се тај јаз стално смањује. Јер, као што већина наших искусних и квалификованих спортских психолога истовремено обавља обе улоге, тако се не може рећи да се само академски спортски психолози фокусирају на научна истраживања и едукацију, а практичари само на практични рад са учесницима у спорту. Ова тврдња заснована је на чињеници да су нека од најзначајнијих фундаменталних домаћих истраживања у домену психологије спорта покренута управо од стране психолога практичара и реализована у стручним спортским институцијама. Добри примери су истраживање карактеристика личности и мотивације спортиста различитог нивоа успешности које је реализовано у Заводу за спорт крајем 1970-их, или истраживање врста и степена насиља у спорту Србије, као и психо-социјалних и ситуационих фактора, који га подстичу, такође изведеног у истој стручној установи током 2008. године.

\section{Психолози и кадрови за занимање психолог спорта}

Када се говори о карактеристикама развоја психологије спорта у Србији, логично се намеће питање како је она изгледала на својим почецима, како касније, када је постала потпуно призната и прихваћена од свих учесника у спорту, а како данас када наша академска, а посебно спортска пракса врви од психолога који се баве различитим проблемима и темама, од појединаца који себе са правом или без икаквог основа називају спортским психолозима, менталним тренерима или тренерима психолошких вештина. У раној фази која се везује за период од 1962. до 
почетка 1980-их година, домаћа психологија спорта прешла је дуг пут у коме је стасавала као самостална научна дисциплина трудећи се да дође до аутентичних метода, специфичних теорија, мера и тестова за процену (психолошко профилисање спортиста), модела психолошке припреме, метода психолошког саветовања и програма за побољшање извођења. Треба рећи да у то време, као нажалост ни данас, у Србији није постојао никакав званични систем нити програм школовања спортских психолога на факултетима матичним за психологију, већ су се ретки дипломирани психолози, вођени искључиво сопственим интересовањем и љубави према спорту, опредељивали да стечена психолошка знања потпомогнута личним спортским искуствима, пренесу у спортску праксу како би појединачним спортистима и спортским тимовима (од клупских до националних селекција) помогли да превазиђу бројне психолошке баријере које их спречавају да реализују своје спортске потенцијале. Врло брзо су схватили да постојећи психолошки тестови и теорије које су наследили из опште или клиничке психологије, а намењени су општој или популацији особа са психолошким поремећајима, нису ни адекватни ни довољни за психолошку процену спортске и вежбовне популације, да се у свом раду морају ослањати на знања из других спортских наука, да се њихов саветодавни и терапијски рад знатно разликује од оног који се одвија у традиционалним психотерапијским околностима, како по местима, контекстима и условима у којима се одвија, тако и по етичким питањима и дилемама са којима се сусрећу. Оваква и слична питања морали су решавати ослањајући се на сазнања психолошке науке и праксе развијених земаља, а посебно је то било важно у домену психолошке дијагностике, психолошке припреме и тренинга менталних, вештина.

\section{Од методолошког прилагођавања до интеракционог приступа у процесу сазнања}

Домаћи спортски психолози су континуирано пратили савремена достигнућа у својој науци, преводили и адаптирали нове психолошке тестове настале специфично за спортисте и вежбаче, тестове који су уважавали карактеристике специфичних спортских ситуација с једне стране и карактеристике црта, стања или расположења спортиста с друге стране, како би боље разумели и успешније предвидели њихово понашање. Већ крајем 1970-их, наши спортски психолози практичари су се у процесу психолошке дијагностике, односно утврђивања актуалног психолошког статуса (релевантних психолошких карактеристика, црта и стања, предности и слабости, потенцијалних проблема у такмичарском извођењу, односима у тиму, комуникацији са саиграчима и тренером итд.) као основе за све друге видове своје активности (Бачанац, 2010), потпуно преоријентисали на ситуационо специфичне тестове, тј. усвојили су интеракциони приступ. То значи да нису више процењивали патолошке конативне факторе попут генералне анксиозности, компулзивности, фобичности, хистерије, хипохондрије, депресије, хипоманичности, психотичности итд., већ су користили инвентаре личности намењене нормалној популацији (нпр. Eysenckovi упутници JEPQ, EPQ, Cattellovi инвентари HSPQ i 16 PF, инвентар Coste i McCrea NEO-PI-R, Leea i Ashtona HEXACO-PI-R итд.), као и велики број нових тестова за процену црта и стања специфичних за спорт, као што су тестови: црте и стања такмичарске анксиозности (SCAT, SAS, CSAI-2), спортског самопоуздања (TSCI, SSCI), упитници спортске мотивације (AMI, MSP, PMQ, COQ, SMS-28), интринзичке мотивације (IMI), тестови пажње и интерперсоналног стила, стресних ситуација у различитим спортовима (TTAIS, RSIFT, CCBQ), Инвентар превладавања стреса у спорту (ACSI), Упитник за регулацију емоција (EPQ), скале за мерење лидерског стила, кохезивности спортских тимова, мотивационе климе (LSS, GEQ, PMCQ) итд.

Неки од поменутих тестова, као и бројни други, настали су у периоду од 1990-их и након 2000. год., а њихови називи довољно говоре о ширини тема којима се савремена психологија спорта данас бави. Они третирају проблеме у вези са „сагорелошћу“ (burnout) спортиста, тренера и судија, питањима спортског идентитета и његовог мерења, позитивним и негативним странама перфекционизма код спортиста, процењују флоу стање (стање понесености у коме се остварују највећа постигнућа), процењују психолошке стратегије које спортисти користе 
за време тренинга и такмичарског извођења, ставове према менталном тренингу и искустава у његовом коришћењу, користе биофидбек апарате за саморегулацију аутономних биолошких функција у сврси превладавања такмичарског стреса и притиска, перцепцију односа тренерспортиста, врсте тренерског фидбека, процењују емоције спортиста, стил комуникације тренера, колективну ефикасност, мотивациону климу за младе спортисте, задовољства спортиста, мере самолидерство код спортиста, такмичарску оријентацију, комуникационе вештине (нпр. вештину слушања), мултидимензионалну спортсменшип оријентацију и др.

\section{Иновациона страна психолога спорта у Србији}

Поред превођења и адаптације различитих психолошких инвентара страних аутора, домаћи спортски психолози, превасходно запослени у 3СМСРС, на основу резултата сопствених истраживања, личних професионалних искустава, актуалних теоријских приступа у психологији спорта и уважавања специфичности домаће спортске популације, развијају сопствене аутентичне дијагностичке инструменте који им омогућавају да њихова процена спортиста буде што објективнија, а даље активности које се на њој базирају, у што већем степену компатибилне са стварним потребама и интересима појединаца и тимова. Неки од њих су: упитници за процену бројних индикатора социјалног статуса младих спортиста, одраслих спортиста, спортских тренера, судија, фитнес инструктора; упитници за мерење мотива спортског и општег постигнућа, упитник оцене важности тренерских квалификација и атрибута, ревидиран и допуњен упитник за процену такмичарске анксиозности, упитници стресних ситуација у оријентирингу, социометријски упитници, упитници за мерење лично доживљеног насиља код различитих актера у спорту, упитници за процену фактора који доприносе насиљу и мера за његову превенцију, упитници праћења стања током извођења, ментални планови наступа за спортисте у различитим спортским дисциплинама итд.

Поменуте активности психолога практичара, као и њихово континуирано залагање да у свом раду примењују проверене методе и моделе, да се придржавају највиших стандарда добре праксе и етичких постулата своје професије, као што су компетентност, поверљивост, постављање граница, стручна, научна и социјална одговорност, интегритет, лично понашање, етика у истраживању (APA Division-47, Policies \& Procedures, 2011; FEPSAC, Position Statement 9, 2011). Ови принципи су од подједнаке важности за све спортске психологе, без обзира да ли се баве истраживањима, едукацијом или су ангажовани у непосредној пракси. Ипак, чини се да су изазови примењених спортских психолога највећи, јер они често раде у нестандардним условима, па су етичке смернице успостављене од Америчког психолошког удружење (АПА) и Друштва психолога Србије (ДПС, 2000) за њих често неадекватне, сувише ригидне и нефлексибилне, јер су усмерене на традиционалну психолошку праксу и не уважавају специфичности сложене психолошке праксе у спортској средини. У том правцу говори и недавно истраживање о уверењима студената психологије у вези са етичким понашањем спортских психолога. Оно је потврдило висок степен неразумевања етичких дилема ове професије, као и потребу да се развију специфични програми за обуку из етике примењене психологије спорта, како би се минимизирале инхерентне тешкоће у њиховој пракси (Весковић и Петровић, 2017).

\section{ПСИХОЛОГИЈА СПОРТА У СРБИЈИ - СУТРА}

Након 55 година стасавања и сазревања примењене и академске психологије спорта у Србији, може се констатовати да је она данас равноправни члан велике породице спортских и психолошких наука. Како још увек постоје појединци који немају праву представу чиме се то психологија спорта бави и коме је све намењена, као ни праву слику о њеним могућностима и ограничењима (неки преувеличавају моћ спортских психолога, други их сасвим обезвређују), то је перманентни задатак спортских психолога, и академских и практичара, да о свим аспектима своје професије континуирано едукују све учеснике у спорту. Само тако садашњи и будући спортски психолози ће имати праву подршку, помоћ и разумевање 
тренера, родитеља спортиста, стручњака из медицине спорта, биомеханике, дијететичара, спортских званичника и других директних и индиректних учесника у спорту и вежбању. То је предуслов да све већи број ових професионалаца буде ангажован у спорту, да се њихово ангажовање тражи и адекватно вреднује.

Едукација је моћно средство које може помоћи да се неке уобичајене предрасуде, контроверзе и митови у вези са психологијом спорта и спортских психолога, који и данас постоје, али далеко мање него нпр. 1970-их и 1980-их година прошлог века, у потпуности искорене или бар сведу на најмању меру. Чак и данас, на срећу за ретке појединце, користити услуге спортских психолога представља стигму, јер верују да је стручна помоћ ових професионалаца потребна само ментално слабим спортистима са мање или више озбиљним психолошким проблемима или поремећајима. Ово је само један од укупно 32 мита које наводе Кол и Кол (Cole, Cole, 2017). Они наводе да се погрешна уверења, предрасуде и митови о могућностима и користима психологије спорта крећу од оних који је потпуно негирају и обезвређују, до оних који је глорификују и нереално сагледавају (нпр. спорт је 90\% ментална активност; психологија спорта нуди брза и лака решења; психологија спорта може губитника претворити у победника; психологија спорта преузима контролу над спортистима и ставља је у руке спортских психолога; психологија спорта може гарантовати врхунско извођење спортском тиму; психологија спорта је једноставно хипнотисање спортиста итд.). Осим едукације, редуковању оваквих погрешних уверења и митова, највише може помоћи етичко поступање спортских психолога, свесност о сопственим квалификацијама и стручност и одговорност за тачно и поштено представљање клијентима, без преувеличавања могућности или глорификовања својих улога. Само социјално одговорним понашањем у најбољем интересу својих клијената и у складу са етичким стандардима професије, они ће штитити лични интегритет, интегритет и достојанство своје професије и ојачати поверење у психологију спорта.

Међутим, за квалитетно обављање интер и мултидимензионалне улоге, спортски психолози се морају добро припремити, стећи адекватно образовање и додатна знања како из психологије спорта, тако и из других простора спортских, друштвено хуманистичких и медицинских наука које су са њом повезане. На самом почетку практиковања ове професије код нас, било је довољно да се појединци само назову спортским психолозима и почну да раде у спорту, а да претходно нису стекли никаква додатна знања из психологије спорта. На исти начин, не схватајући специфичности науке и праксе ове дисциплине, писали су и прве књигечији садржај сучиниле теме из опште, развојне и/или педагошке психологије којима су само додаване одреднице везане за спорт (нпр. емоције у спорту, личност спортиста, мотивација у спорту, анксиозност и спорт и др.). На срећу, данас то више није тако. Стасала је нова генерација психолога, од којих су неки прошли озбиљну супервизирану праксу у Заводу за спорт и медицину спорта Републике Србије чија је психолошка лабораторија од почетка 1990-их па до данас била једино референтно место за стручну обуку и тренинг младих психолога који су, или у оквиру редовне студентске праксе или као волонтери, стицали основна знања из свих домена своје будуће активности. Под супервизијом и вођењем искусних психолога практичара, они су добијали знања за квалитетно обављање психолошке процене спортиста, упознавали се са њеним ограничењима, принципима етичности и упозоравани на могуће последице нестручног и неетичког руковања добијеним подацима.

\section{I Дефинисање оквира деловања спортског психолога - од декларативног и проблемског до контекста целовите професионалне компетентности}

Спортски психолози обављају бројне функције у зависности од тога где раде, са којим проблемима им се спортисти, тренери, родитељи спортиста, вежбачи или други учесници у спорту и вежбању обраћају, да ли су примарно едуковани из психологије или спортских наука, каква су им искуства у раду са спортистима, да ли лично преферирају рад на клиничким проблемима (анксиозност, депресија, поремећаји исхране, зависна понашања - коцкање, злоупотреба дрога), или преферирају консултативно саветодавни рад, обучавање менталним вештинама, научно истраживачи рад, дизајнирање програма за ефикасније стицање и примену моторних вештина итд. 
Неки спортски психолози највише се ангажују на унапређењу различитих аспекта дечијег и омладинског спорта - едукују тренере и родитеље како да младим спортистима обезбеде позитивна искуства у спорту, развију им самопоуздање, самопоштовање, вредне социјалне вештине, снажан спортски карактер, трајну љубав према спорту и здравом начину живота. Друге више мотивише рад са врхунским спортистима и тимовима, како би континуирано манифестовали висока такмичарска постигнућа и спорт избалансирали са осталим сферама свог живота.

Академски оријентисани спортски психолози запослени у високошколским установама, настоје да студентима пренесу вредна знања из психологије спорта која ће сутра моћи да примене у свом раду. Све више је спортских психолога који раде са физички и ментално хендикепираним особама којима бављење спортом није само у функцији остварења запажених такмичарских резултата, већ значајна терапијска активност, средство ресоцијализације, психолошког оснажења, грађења самопоштовања и самопоуздања, квалитетнијег живота и свеопштег благостања. Не треба заборавити стално растући број спортских психолога који се баве применом психолошких принципа на промоцију физичке активности у слободном времену, последицама те активности на ментално здравље и кондицију, прописивањем вежбања као средства за психотерапију и стратегије управљања стресом, баријерама за вежбање, теоријама и моделима вежбовног понашања, когнитивним и бихевиоралним стратегијама за промоцију интринзичке мотивације за вежбање и преданости вежбању, итд. Овим и другим проблемима бави се посебна супдисциплина психологије спорта, коју Аншел (Anshel, 2007) назива Примењена психологија вежбања.

Ако се запитамо због чега се људи обраћају спортским психолозима за помоћ, онда је то на првом месту њихова жеља да побољшају своје спортско извођење, тј. такмичарске резултате (Le Unes, 2011), затим да науче да контролишу високе нивое такмичарске анксиозности, стреса и притиска које доживљавају неколико дана пре такмичења, непосредно пред наступ и током извођења, што знатно умањује квалитет њиховог наступа и спречава их да реализују тренутно достигнути ниво спортске форме. Када родитељи своју децу или младе спортисте доведу код спортског психолога, они најчешће као разлог тражења помоћи наводе следеће: „Знате, он/она је на тренингу перфектан/на, може да уради све без грешке и на високом нивоу квалитета. Али, на такмичењу је то потпуно друга особа, не можете га/је препознати - губи од слабијих противника, прави почетничке грешке, као да једва чека да се меч/утакмица заврши“; или „Тренери ми говоре, а и ја тако мислим да је он/она одличан играч, физички и технички на највишем нивоу, само да му/joj «средимо главу〉 и биће непобедив/а“. Већ након првог разговора (експлоративног интервјуа) са спортистом, искусни психолог открива и бројне друге проблеме који могу бити у вези са притиском родитеља, негативним приступом тренера, високим очекивањима, неспособношћу да се ускладе школске и спортске обавезе, неприхваћеношћу или нејасном улогом у тиму, високом одговорношћу, осећањем кривице након лошег наступа, страхом од грешке, оријентацијом на избегавању неуспеха, критицизмом и сталним незадовољством родитеља, обимом и интензитетом тренинга неусклађеним са узрастом, фаворизовањем појединаца у тиму, доживљеном повредом и страхом од нове, недостатком глобалног и спортског самопоуздања и др. Спортисти се обраћају спортским психолозима и због жеље да обуздају своје емоције, да контролишу оне негативне и дисфункционалне, да управљају сопственом енергијом (постигну стање оптималне активације или побуђености, уђу и одрже зону најбољег извођења, да науче психолошке вештине опуштања, концентрације и имагинације, да убрзају процес опоравка од повреда, да науче фокусирати, преусмеравати и одржавати пажњу, успешније препознавати намере, потребе и мотиве својих саиграча, науче да уживају у спорту, поставе реалне, мотивишуће, довољно изазовне краткорочне, средњорочне и дугорочне циљеве, раде на менталној припреми за такмичење и др. Спортски психолози спортистима и тренерима помажу да унапреде међусобну комуникацију; изграде кохезивни тим, климу оријентисану на мајсторство и међусобну сарадњу; да примењују различите технике за изградњу тима (team building); баве се проблемима транзиције спортске каријере; едукују тренере да препознају симптоме сагорелости и претренираности и 
како да поступају у таквим ситуацијама; како да развијају и одржавају мотивацију спортиста и тимску дисциплину; како да комуницирају са родитељима спортиста, помоћним особљем, члановима стручног тима; како да користе услуге спортских психолога, имплементирају програм тренинга психолошких вештина; препознају и превенирају злоупотребу дрога за повећање извођења и поремећаје исхране; изграде сопствену филозофију тренирања; буду ефикасни лидери; како да се понашају у кризним ситуацијама итд.

Добру слику о томе шта спортски психолози раде може се стећи ако се анализира садржај савремених књига, као што је Коксова Психологија спорта: Концепти и примена (Sport Psychology: Concepts and Applications, 2012) ca 19 тематских поглавља, Основе спорта и психологије вежбања (Foundations of Sport and Exercise Psychology) Вајнберга и Гулда (2011) са 24 поглавља, или Примењена психологија спорта (Applied Sport Psychology) уредника J. М. Вилиамса (Williamsa 2010) са 25 тематских целина. Такође, увид у многоструку и сложену улогу спортских психолога стиче се и на основу садржаја чек листе коју је Лесик (Lesyk, 2005) припремио на основу докумената АПА, Одељење 47 о стручности спортских психолога, а сврха јој је да психолозима практичарима помогне у процени сопствених знања и вештина које су основни показатељи њихове стручности и потребе за одређивањем приоритета у даљем усавршавању. Прву листу чине специфична знања из области теорије и истраживања социјалних, историјских, културних и развојних основа психологије спорта; принципи и пракса примењене психологије који укључују области и технике психолошке процене специфичне за спорт, тренинг менталних вештина за побољшање спортског извођења и задовољства бављењем спортом; проблеми клиничког и саветодавног рада са спортистима; организациони и системски аспекти саветовања у спорту; разумевање развојних и социјалних питања у вези са бављењем спортом; знања о бихевиоралним основама спорта и вежбања (нпр. психологија вежбања, моторно учење, медицина спорта). Друга листа садржи 10 области знања о личности и групама: млади спортисти и спортске организације; средњошколски спортисти и спортска одељења; спортисти на факултетима и спортска одељења; професионални спортисти, тимови илиге; спортисти ветерани иорганизације; повређени спортисти; елитни спортисти и спортске организације (нпр. олимпијски спортисти и државни управни органи); спортисти рекреативци; спортисти са сталним инвалидитетом; људи који су укључени у спорт али нису директни учесници (нпр. породице, тренери, администратори, функционери). Трећа листа садржи 26 специфичних вештина коje ce директно односе на оно што спортски психолози раде са појединцима или тимовима: тренинг психолошких вештина за спортисте; постављање циљева и профилирање извођења спортиста; визуализација и планирање извођења; повећање самопоуздања спортиста; когнитивнобихевиоралне технике саморегулације за спортисте; тренинг контроле и управљања емоцијама; атрибуција интерпретације и самопроцене у спорту; поремећаји исхране и интервенције управљања телесном тежином за спортисте; злоупотреба дрога и интервенције намењене спортистима; поступање при коришћењу ергогених помагала/суплемената за извођење спортиста; саветовање спортиста у вези са тугом, депресијом, губитком, суицидом; саветовање о претренираности и сагорелости; саветовање у вези са полним идентитетом; о агресији и насиљу у спорту; спортске повреде и рехабилитација; транзиција каријере и идентитет у спорту; тренинг (обука) тимске кохезије; тим билдинг; обучавање лидерства; вештине консултације (саветовања) за спортске организације и системе; развој морала, карактера и спортсменшипа у спорту; когнитивно емоционални и развојни проблеми и развој талента у спорту; саветовање о мотивисању спортиста; развој самопоуздања, самопоштовања и компетенција у спорту; интервенције усмерене на укључивање родитеља и породице у дечији и омладински спорт.

И да закључимо, све наведене активности спортских психолога обављају и наши психолози практичари, али не са подједнаком учесталошћу, јер захтеви наших спортиста, тренера и родитеља када се обраћају спортским психолозима превасходно се односе на стручну помоћ да се побољша спортско извођење, смањи висока анксиозност, формира правилна такмичарска оријентација (на постизање успеха, а не избегавање неуспеха), ојача самопоуздање, науче технике регулисања и управљања енергијом, емоцијама, физиолошком 
и психолошком активацијом - једном речју да се смањи јаз између сопствених реалних потенцијала, достигнутог нивоа спортске форме и онога што показују у ситуацијама такмичења. За разлику од самих почетака домаће психологије спорта када су спортски психолози највише посла имали са тзв. „проблем спортистима“, данас они највише раде са „добром децом“, младим или одраслим спортистима који желе да дају свој максимум, буду задовољни својим извођењем и уживају у спорту којим се баве.

\section{II Изазови професије и занимања спортски психолог}

Нажалост, данас је на сцени и велики број самопроглашених спортских психолога у чијем раду се уочава кршење основних начела етичности и интегритета професије и занимања, јер на неки начин обмањујусвојебудућекориснике, агресивно се рекламирају, а на различитим друштвеним мрежама се представљају као спортски психолози, а при томе не дају никакве информације о сопственој стручности и едукованости за ту професију. Оваквом стању сигурно доприноси непостојање струковних-сталешких удружења, оквира квалификација, и регулатива о томе ко је спортски психолог, каву едукацију треба да има и које називе може користити. Јер неко ко има примарно образовање из спортских наука, а на мастер студијама је стекао одређена знања из једне уске области психологије спорта (нпр. о тренингу различитих менталних вештина у појединим спортовима), себе не може називати и представљати се као спортски психолог. На западу и САД такви стручњаци се називају саветницима или едукаторима у области психологије спорта или менталним тренерима, а спортски психолози су особе које су стекле примарно образовање из психологије и додатну едукацију из спортских наука. Спортски психолози би што пре требало да се удруже и организованоделују како би успешније решавали проблеме са којима се свакодневно сусрећу, а тичу се нормативног регулисања сопствених квалификација, успостављања програма обавезне едукације, супервизиране праксе, етичког кодекса и др. То могу само ако се организују као секција за психологију спорта у оквиру Друштва психолога Србије у чијем саставу функционише више од 25 секција из различитих грана или области психологије. На IX конгресу психолога Југославије у Врњачкој Бањи 1988. године, покренута је иницијатива да се на нивоу тадашње Државе формира удружење или секција спортских психолога. Чак су, колико се аутор овог рада сећа, предложени председник и генерални секретар будуће асоцијације, али до реализације те идеје никада није дошло. Много година касније, тачније 2012. та идеја је реализована када је у Београду званично формирано и регистровано прво удружење спортских психолога, Секција за психологију спорта у оквиру Друштва психолога Србије. Секција је у моменту оснивања бројала 22 члана. Нажалост, била је кратко активна и већ након годину дана њене активности у потпуности замиру.

Да би боље разумели садашњост психологије спорта, вратимо се на тренутак у 1975. годину. Те године је спортски психолог Љубиша Лазаревић први пут званично био у пратњи југословенских спортиста на Медитеранским играма у Алжиру. Та пракса рада на терену, пружања психолошке помоћи на великим такмичењима, настављена је, истина не и континуирано, до данас. Од 1984. па све до 2009. спортски психолози су припремали спортисте за све велике међународне наступе (ЕП, СП, ОИ), али на та такмичења са њима нису ишли. Многи фактори, углавном невезани са оспоравањем чињенице да је психолошка подршка на таквим догађајима често и кључна компонента доброг такмичарског наступа, утицали су на такво понашање најодговорнијих појединаца из спортских институција, као што су некадашње СОФК-е (Савез организација за физичку културу), СИЗ-ови физичке културе (Самоуправне интересне заједнице), министарства задуженог за спорт и самог националног олимпијског комитета. Поновно редовно присуство спортских психолога у стручним телима олимпијских делегација, обновљено је 2009. године на Летњем олимпијском фестивалу младих Европе (ЕYOF) у Финској, настављено 2011. на ЕYOF-у у Трабзону, Олимпијским играма 2012. у Лондону и 2016. у Рију. Надамо се да ће свој дијагностички, едукативни и саветодавно-консултативни рад са спортистима психолози и даље редовно практиковати и на другим великим такмичењима, јер сам одлазак и адаптација на атмосферу која влада у олимпијском селу или сличним центрима у којима борави велики број познатих спортиста 
и спортских звезда из целог света, код многих неискусних спортиста може изазвати велики стрес, притисак, одвлачење пажње са личних такмичарских циљева, неусредсређеност на раније успостављене тренажне и такмичарске рутине и сл., што је сигуран пут (посебно код спортиста који нису у пратњи својих тренера) ка лошем такмичарском наступу.

\section{III Национална спортска психологија кроз учење и примену психолошких вештина}

Више пута је наглашено да је психолошка дијагностика или профилисање спортиста основа активности спортских психолога. Она је први корак након кога они одлучују које су области њихових даљих интервенција, да ли је неопходно спортисту или све чланове тима обучавати психолошким вештинама, за који модел ће се определити и које вештине ће тренирати (концентрације и фокусирања пажње, технике опуштања, технику визуализације, постављања циљева, грађења самопоуздања, изградње тима, колективне ефикасности итд.), да ли ће организовати едукативне сесије намењене тренерима и/или родитељима, радити на развоју интринзичке мотивације итд. Спортски психолози и ментални тренери код нас, као и они у свету, највише раде на обуци спортиста психолошким вештинама које доприносе успеху у датом спорту, а исто тако су подједнако употребљиве и корисне за живот ван спорта. У зависности од стечених знања из психологије спорта и спортских наука, познавања одређених психотерапијских и саветодавних техника, искустава у раду са спортистима и теоријских оријентација - при пружању својих услуга спортски психолози примењују различите моделе. Поквардовски (Poczwardowski et al., 2004, према Aoyagi i Poczwardowski, 2012) их сврстава у пет категорија: (а) моделе тренинга/обуке психолошких вештина (ТПВ), (б) моделе саветовања, (ц) медицинскемоделе,(д)моделеинтердисциплинарне спортске науке, и (е) супервизиране моделе саветовања са интегративним приступом. Унутар модела тренинга психолошких вештина, издвајају се две шире групе: у првој су модели фокусирани на психологе практичаре који пружају саветодавне и консултантске услуге спортистима (нпр. модел когнитивно-бихевиоралних консултација, модел саветовања младих спортиста, модел вођења успешног саветовања), док су у другој модели директно усмерени на развој психолошких вештина у циљу постизања спортске изврсности (Ханинов модел индивидуалних зона оптималног функционисања, пирамидални модел спортске изврсности, модел резонантног извођења Нибарга и сар., Орликов точак изврсности, Верначијев модел врхунског извођења, интегративни модел људског извођења Гарднера и Мура, модел менталних вештина за спортисте и тренере Робин Вили.

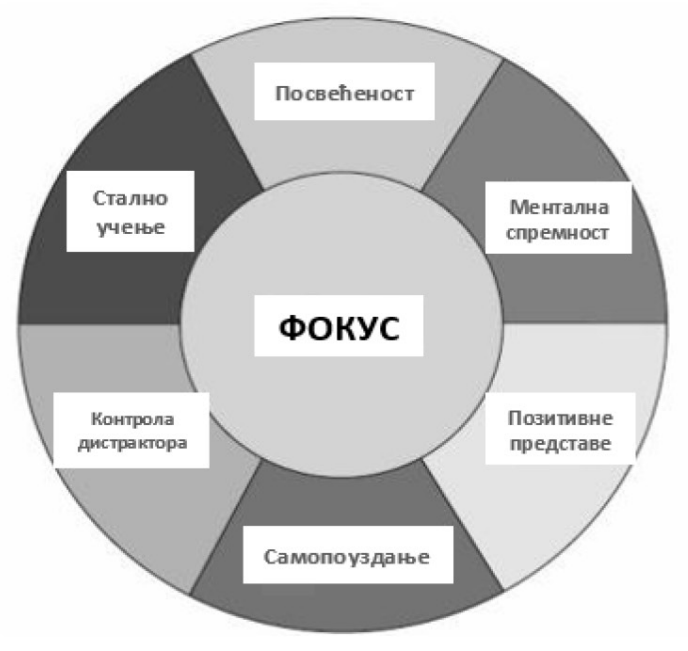

A

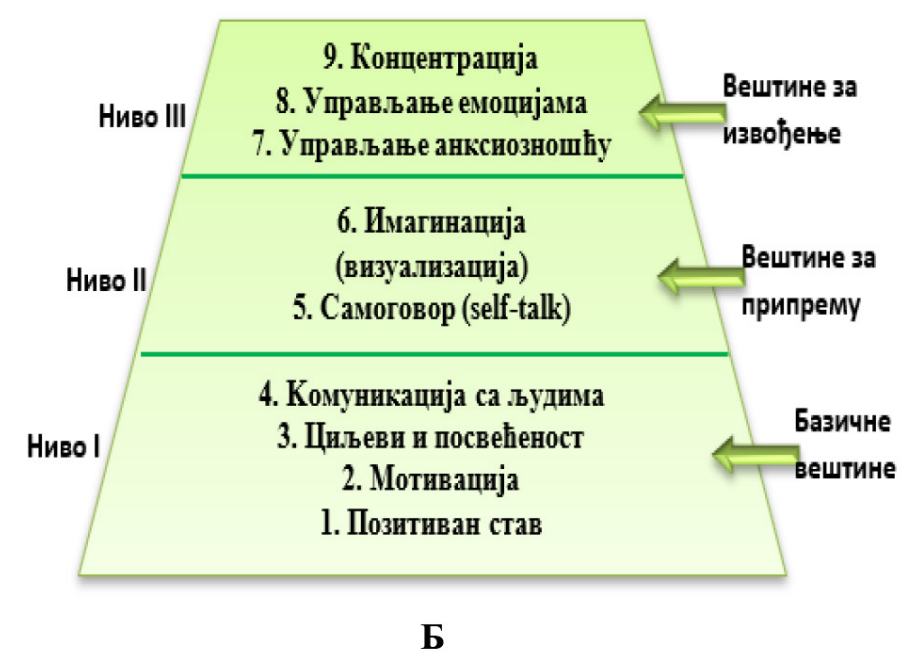

Б

Слика 1. А: Точак изврсности (преузето од Orlick, Т. 2008, str. 12); Б: Девет менталних вештина (прилагођено према Lesyk, 2007) 
Без обзира о ком моделу се ради, сви они у суштини садрже обучавање сличних психолошких вештина, само им је теоријски приступ и њихово рангирање по важности или намени различито. Узмимо за пример Олриков модел точка изврсности (Orlick, 2008) који се састоји од од седам критичних елемената који по њему спортисту воде ка изврсности или мајсторству (слика 1А). То су: фокус (најважнији елемент изврсности, језгро или центар круга), посвећеност (кључни састојак стремљења ка изврсности), ментална спремност (да се уради све како би спортиста био позитиван, фокусиран, истрајан, потпуно посвећен својим циљевима), позитивне визије и представе (коришћење снаге позитивних визија, мисли, менталне имагинације, визуалитизације), самопоуздање (веровање у своје потенцијале, способности да се савладају препреке и постигну циљеви, у своју менталну спремност, свој фокус, свој избор, значај своје мисије и оне за које се ради или игра), контрола ометања (способност да се контролишу спољни и унутрашњи дистрактори) и непрекидно учење (стално учење, ширење граница и самооткривање спортисту води спознаји када постиже најбољи фокус и извођење). За разлику од Орлика чији модел подразумева примарну усмереност психолога на обучавање спортиста вештинама које садржи његов точак изврсности, Вилијин Модел менталних вештина за спортисте и тренере (Vealey, 2007, према Aoyagi i Poczwardowski, 2012) обједињује различите врсте менталних вештина које утичу и на извођење и добробит појединаца и тимова. Модел укључује четири категорије менталних вештина: базичне вештине, вештине извођења, вештине личног развоја и тимске вештине. Базичне менталне вештине неопходне за успех чине: мотив постигнућа, самосвесност, продуктивно мишљење и самопоуздање. Вештине које се користе током извођења састоје се од перцептивно-когнитивних вештина, фокуса пажње и управљања енергијом. Вештине личног развоја омогућавају ефикасно психолошко функционисање, а укључују изградњу личног идентитета и интерперсоналне компетентности. Тимске вештине су квалитети неопходни за ефикасну тимску средину и успех, а садрже тимско поуздање, кохезију, комуникацију и лидерство.

Модел најсличнији Вилијином је Лесиков (Lesyk, 2007) модел пирамиде извођења, заснован на његовом уверењу да се из свих постојећих модела могу издвојити девет специфичних менталних вештина које доприносе успеху у спорту (слика 1Б). Оне чине пирамиду извођења у чијој се основи или на првом нивоу налазе базичне вештине неопходне за постизање дугорочних циљева, учење и одржавање дневних тренинга. Оне су потребне свакодневно у дужем временском периоду, често месецима и годинама, а чине их: позитиван став, мотивација, циљеви и посвећеност и вештине комуникације са људима. На другом нивоу су вештине које спортисти користе непосредно пре извођења и служе као припрема за извођење: вештина коришћења позитивног самоговора и вештина менталне имагинације или визуализације. На трећем нивоу или врху пирамиде налазе се вештине које се користе током актуалног извођења, а чине их вештине ефикасног управљања анксиозношћу, управљања емоцијама и одржавања концентрације. Ове вештине се уче и унапређују кроз инструкције и вежбање, а њихову обуку психолози започињу проценом знања спортисте у примени сваке од њих (обично користе Тест стратегија извођења - TOPS који мери у ком степену спортисти у специфичним ситуацијама на тренинзима и такмичењима користе вештине постављања циљева, аутоматског извођења, контроле емоција, имагинацију, активацију или постизање оптималне побуђености, самоговор, релаксацију, негативно мишљење, контролу пажње. Након тога развијају план за обучавање и усавршавање специфичних вештина које су том спортисти потребне. Наравно, неопходно је и периодично преиспитивање способности спортисте у свакој вештини, како би се проценио постигнути напредак.

\section{IV Психологија спорта кроз спортску и академску кохабитацију}

Потреба за теоријом и праксом психологије се повећава како у националним спортским федерацијама и клубовима, тако и у стручним и академским институцијама у области спорта. Сваки већи национални спортски савез, као и велики клубови, траже једног или више спортских психолога који ће за њих радити. Ангажовање спортских психолога од стране родитеља спортиста од краја 1990-их у сталном је 
порасту, па се они морају посебно припремити за разумевање психодинамике породичних односа и њеног утицаја на спортску каријеру деце. Спортски психолози ће се све раније укључивати у рад са младим спортистима, њиховим тренерима и родитељима, што доприноси да се негативна спортска искуства сведу на најмању меру, да родитељи правилно схвате своју улогу и да је на најбољи начин одиграју, да тренери остваре добру комуникацију са спортистима и њиховим родитељима, усвоје позитиван приступ тренирању и креирају климу оријентисану на мајсторство, учење доброг спортског понашања, фер-плеја и животно вредних вештина, да препознају васпитне потенцијале спорта и прихвате се улоге васпитача младих и њиховог припремања да постану здрави, задовољни и продуктивни чланови друштва. Такође, неопходно је да нове генерације спортских психолога уз подршку старијих и искуснијих колега, реше горући проблем стручног оспособљавања и лиценцирања за клиничку и саветодавну праксу у области спорта и физичког вежбања, да успоставе регистар са именима психолога који су испунили захтеве квалификованости за улогу спортских едукатора и/или консултаната психологије спорта, да донесу етичке кодексе који ће уважавати специфичности њихове праксе и да формирају струковну организацију (удружење или секцију) која ће се старати за креирање и спровођење свих стручних и законодавних мера и активности у сврху унапређења теорије и праксе психологије спорта и вежбања и допринети да се смањи број нерегистрованих и неквалификованих појединаца чије је деловање и понашање у конфликту са високим етичким стандардима психолошке професије.

\section{V Спортски психолог - искорак ка новим супспецијализацијама, улогама и технологијама}

Спортски психолози се морају на време припремити за нове супспецијалности у оквиру психологије спорта. Као што се психологија спорта још средином прошлог века одвојила од моторног учења и моторне контроле, данас се у оквиру ње појављују нове супспецијалности, као што је психологија вежбања, развој животних вештина младих кроз спорт и психологија изврсности у извођењу (примена принципа за повећање извођења из психологије спорта на друге области, као што је уметност, музика и бизнис). По мишљењу савремених психолога (Weinberg i Gould, 2011; Zaichkowsky, 2006) уз традиционална квантитативна истраживања, све више ће се користити ненумеричке, квалитативне истраживачке методе. Покрет позитивне психологије који се одавно усталио у домену психологије генерално, у психологији спорта привлачи све више пажње, јер наглашава потребу да се спортски психолози више фокусирају на развој позитивних атрибута спортиста, као што су оптимизам, нада, мудрост, креативност, храброст, одговорност, хумор и срећа насупрот фокусирању на њихове недостатке. Позитивна психологија спортским психолозима отвара нове могућности да своја знања стечена у спорту пренесуу друге области у којима се, такође, захтева врхунско извођење, као што је бизнис, уметност, плес. Верујемо и да ће академски спортски психолози проширити своје улоге (неки то већ јесу), тј. да се неће држати само улоге предавача и реализатора формалног наставног програма психологије спорта, већ ће прихватити улоге саветника и консултанта у раду са студентима о темама које их интересују (нпр. носталгија за кућом и немогућност да се фокусирају на учење, злоупотреба дрога, поремећаји расположења, поремећаји исхране, балансирање академских и спортских обавеза), као и да се ангажују на формирању и раду у саветодавном центру за студенте спортисте при својим факултетима или у раду са спортистима ван факултета (McCann, 2005).

Тржиште рада за ову професију биће ограничено (највише географски, јер све околне земље од којих су неке биле редовни корисници услуга психологије спорта Србије, сада имају сопствене стручњаке чији ће број у будућности бити све већи), па је потребно тражити и примењивати нове начине и методе рада са широком групом могућих клијената. Чињеницу да смо дубоко загазили у свет дигиталне културе, спортски психолози никако не смеју игнорисати, већ своју праксу прилагодити тој реалности. Другим речима, велики број данашњих спортских психолога своје услуге пружају путем интернета, скајпа, вибера и других савремених средстава телекомуникација, која клијентима омогућавају 
да успоставе контакт са њима без обзира у ком делу света се налазе. Ипак, психолози морају бити свесни чињенице да ова савремена технологија, ма колико била привлачна и лако доступна, са собом носи и одређена ограничења и непредвидљиве изазове (Schinke, Hancock, Dubuc, \& Dorsh, 2006). Неки клијенти имају снажну потребу за

\section{ЛИТЕРАТУРА}

1. About Division 47 (2018). Preuzeto sa http:// www.apadivisions.org/division-47/about/

2. American Psychological Association Division 47 Exercise \& Sport Psychology Policies \& Procedures (2011). Preuzeto sa http://www. apadivisions.org/division-47/about/policies .pdf

3. Anshel, M. H. (2007). Applied Exercise Psychology: A practitioner's Guide to Improving Client Health and Fitness. New York: Springer <publishing Company, Inc.

4. Aoyagi, M. W. \& Poczwardowski, A. (2012). Models of Sport Psycholoy Practice and Delivery. In S. Hanton and S. D Mellalieu (eds.), Professional Praactice in Sport Psychology: A Review (pp. 5-30). Abingdon, Oxon: Routledge.

5. APA Division-47 (2009). What Is Exercise Psychology and Sport Psychology? Preuzeto sa http://www.apadivisions.org/division-47/about/ resources/what-is.aspx

6. Assotiation for Aplied Sport Psychology - APA (2018). About Applied Sport \& Exercise Psychology. Preuzeto sa http://www. appliedsportpsych.org/about/about-appliedsport-and-exercise-psychology/

7. Bačanac, Lj. (2007). Psihološka dijagnostika u sportu - Aktualno stanje i savremene tendencije. Međunarodna naučna konferencija „Analitika $i$ dijagnostika fizičke aktivnosti“, Zbornik radova (pp. 302-317). Beograd: Univerzitet u Beogradu; Fakultet spota i fizičkog vaspitanja.

8. Bačanac, Lj. (2009). Psychodiagnosis of athletes: Past, Present and Future. In N. Dikić (Ed). Programme and Abstract Book (pp. 175-197). Belgrade: Fourth Congress of Sports Medicine and Sports Science of Serbia, 22-24 septembre 2009, Belgrade). саветовањем кроз лични контакт, па им физичка одвојеност може бити знатна препрека. И као што Шинки и сар. спекулишу (2006), можда ће будуће технологије ову комуникацијску одвојеност убрзо премостити на начине који су данас незамисливи.

9. Bačanac, Lj. (2015). Elementi psihologije sporta autorizovana skripta. Beograd.

10. Cei, A. (2011). Ferruccio Antonelli: His work and legacy. International Journal of Sport and Exercise Psychology, 9(4), 356-361.

11. Cole, B. \& Cole, W. B. (2017). Myths About Sports Psychology: 32 Misconceptions About The Mental Game Of Sports Explained. Preuzeto sa http://www.mentalgame coach.com /articles/ Sports PsychologyMyths.html

12. Cox, R. H. (2012). Sport Psychology: Concepts and Applications, Seventh Edition. New York: McGraw-Hill, Connect Learn Succeed.

13. European Federation of Sport Psychology (1995). FEPSAC Position Statement 1: Definition of Sport Psychology. http://www. fepsac. com/activities/ position_statements/

14. European Federation of Sport Psychology (2011). FEPSAC Position Statement 9: Ethical principles of the European Sport Psychology Federation. Preuzeto sa http://www. fepsac. com/activities/ position_statements/

15. Keegan, R. (2016). Being a Sport Psychologist. London: Palgrave.

16. Kodeks etike psihologa Srbije (2000). Preuzeto sa http://moodle.f.bg.ac.rs/file.php/126/ eticki_ kodeks_dps.pdf

17. Kontos, A. P. and Feltz, D. L. (2008). The nature of Sport Psychology. In T. S. Horn (Ed.), Advances in Sport Psychology, Third Editions (pp.3-14). Champaign, IL: Human Kinetics.

18. Kremer, J. and Moran, A. P. (2008). Pure Sport: Practical Sport Psychology. Hove, East Sussex: Routledge. 
19. Lavallee, D., Kremer, J., Moran, A. and Williams, M. (2004). Sport Psychology: Contemporary Themes. New York: Palgrave Macmillan.

20. Le Unes, A. \& Nation, J. (1999). Sport Psychology - An Introduction. Chicago: Nelson-Hall Publishers.

21. Le Unes, A. (2011). Introducing Sport Psychology: A Practical Guide. London: Icon Books, Ltd.

22. Lesyk, J. (2005). Sport Psychology: Knowledge \& Skills Check List. Preuzeto sa http://www. apadivisions.org/division-47/about/reasurces/ checklist.pdf

23. Lesyk, J. (2007). The Nine Mental Skills of Successful Athletes. Podium Sports Journal. Preuzeto sa http://www. podiumsportsjournal. com/2007/02/17/the-nine-mental-skills-of-asuccessful-athlete/

24. McCann, S. (2005). Roles: The Sport Psychologist. In S. Murphy (Ed.), The Sport Psych Handbook: A complete guide to today's best mental training techniques (pp. 279-291). Champaign, IL: Human Kinetics.

25. Moran, A. P. (2004). Sport and Exercise Psycology: A Critical Introduction. Hove, East Sussex: Routledge.

26. Orlick, T. (2008). In Pursuit of Excelence: How to win in sport and life through mental training. Champaign, IL: Human Kinetics.
27. Schinke, R.J., Hancock, D. \& Dubuc, N. G. (2006). Looking to the Future of Sport Psychology: An Introduction. Athletic Insight - The Online Journal of Sport Psychology, 8(3). Preuzeto sa www. athleticinsight. com/Vol8Iss3/IntroFuture.htm

28. Singer, R., Hausenblas, H., Janelle, C. Eds. (2001). Handbook of Sport Psychology. New York: John Wiley \& Sons, Inc.

29. Tod, D., Thatcher, J. and Rahman, R. (2010). Sport Psychology. New York: Palgrave Macmillan.

30. Vesković, A., Petrović, N. (2017). Etičko obrazovanje $\mathrm{u}$ primenjenoj psihologiji sporta. Fizička kultura, 71(2), 127-136.

31. Weinberg, R. S. \& Gould, D. (2011). Foundations of Sport and Exercise Psychology, Fifth Edition. Champaign, IL: Human Kinetics.

32. Williams, J. M. \& Straub, W. F. (2010). Sport psychology: Past, Present, Future. In J. M. Wiliams (Ed.), Applied Sport Psychology: Personal Growth to Peak Performance, Sixt Edition (pp. 1-17). New York: McGraw-Hill.

33. Zaichkowsky, L. D. (2006). Industry Challenges Facing Sport Psychology. Athletic Insight -The online Journal of Sport Psychology. Preuzeto sa http://www. athleticinsght. com/ vol.8.Iss3/ 